\title{
Aerosol optical properties over Europe: an evaluation of the AQMEII Phase 3 simulations against satellite observations
}

\author{
Laura Palacios-Peña ${ }^{1}$, Pedro Jiménez-Guerrero ${ }^{1}$, Rocío Baró $^{1, \text { a }}$, Alessandra Balzarini ${ }^{2}$, Roberto Bianconi ${ }^{3}$, \\ Gabriele Curci $^{4,5}$, Tony Christian Landi ${ }^{6}$, Guido Pirovano ${ }^{2}$, Marje Prank ${ }^{7,8}$, Angelo Riccio ${ }^{9}$, Paolo Tuccella ${ }^{4,5}$, and \\ Stefano Galmarini ${ }^{10}$ \\ ${ }^{1}$ Physics of the Earth, Department of Physics, Regional Campus of International Excellence \\ (Campus Mare Nostrum), University of Murcia (UMU-MAR), Murcia, Spain \\ ${ }^{2}$ Ricerca sul Sistema Energetico (RSE SpA), Milan, Italy \\ ${ }^{3}$ Enviroware srl, Concorezzo, Italy \\ ${ }^{4}$ CETEMPS, University of L'Aquila, L'Aquila, Italy \\ ${ }^{5}$ Dept. Physical and Chemical Sciences, University of L'Aquila, L'Aquila, Italy \\ ${ }^{6} \mathrm{CNR}$ - Institute for Atmospheric Sciences and Climate, Bologna, Italy \\ ${ }^{7}$ Finnish Meteorological Institute, Atmospheric Composition Research Unit, Helsinki, Finland \\ ${ }^{8}$ Cornell University, Atmospheric and Earth Sciences, Ithaca, NY, USA \\ ${ }^{9}$ University Parthenope of Naples, Dept. of Science and Technology, Naples, Italy \\ ${ }^{10}$ European Commission, Joint Research Centre, JRC, Ispra, Italy \\ ${ }^{a}$ now at: Section Chemical Weather Forecasts, Division Data/Methods/Modelling, ZAMG - Zentralanstalt \\ für Meteorologie und Geodynamik, Vienna, Austria
}

Correspondence: Pedro Jiménez-Guerrero (pedro.jimenezguerrero@um.es)

Received: 3 December 2017 - Discussion started: 5 March 2018

Revised: 31 January 2019 - Accepted: 13 February 2019 - Published: 7 March 2019

\begin{abstract}
The main uncertainties regarding the estimation of changes in the Earth's energy budget are related to the role of atmospheric aerosols. These changes are caused by aerosol-radiation (ARIs) and aerosol-cloud interactions (ACIs), which heavily depend on aerosol properties. Since the 1980s, many international modeling initiatives have studied atmospheric aerosols and their climate effects. Phase 3 of the Air Quality Modelling Evaluation International Initiative (AQMEII) focuses on evaluating and intercomparing regional and linked global/regional modeling systems by collaborating with the Task Force on the Hemispheric Transport of Air Pollution Phase 2 (HTAP2) initiative. Within this framework, the main aim of this work is the assessment of the representation of aerosol optical depth (AOD) and the Ångström exponent (AE) in AQMEII Phase 3 simulations over Europe. The evaluation was made using remote-sensing data from the Moderate Resolution Imaging Spectroradiometer (MODIS) sensors aboard the Terra and Aqua platforms, and the instruments belonging to the ground-based Aerosol
\end{abstract}

Robotic Network (AERONET) and the Maritime Aerosol Network (MAN). Overall, the skills of AQMEII simulations when representing AOD (mean absolute errors from 0.05 to 0.30 ) produced lower errors than for the $\mathrm{AE}$ (mean absolute errors from 0.30 to 1 ). Regardless of the models or the emissions used, models were skillful at representing the low and mean AOD values observed (below 0.5). However, high values (around 1.0) were overpredicted for biomass burning episodes, due to an underestimation in the common fires' emissions, and were overestimated for coarse particles - principally desert dust - related to the boundary conditions. Despite this behavior, the spatial and temporal variability of AOD was better represented by all the models than AE variability, which was strongly underestimated in all the simulations. Noticeably, the impact of the model selection when representing aerosol optical properties is higher than the use of different emission inventories. On the other hand, the influence of ARIs and ACIs has a little visible impact compared to the impact of the model used. 


\section{Introduction}

The Fifth Assessment Report (AR5) of the Intergovernmental Panel of Climate Change (IPCC) ascribes to atmospheric aerosols and clouds the large uncertainty in the estimation of changes in the Earth's energy budget. Atmospheric aerosols produce these changes in two different ways: influencing the Earth's radiation, the aerosol-radiation interactions (ARIs), and modifying clouds and precipitation, the aerosol-cloud interactions (ACIs), which also increase uncertainty due to cloud processes (Boucher et al., 2013).

ARIs and ACIs strongly depend on the optical properties of atmospheric aerosols, along with their atmospheric distribution and hygroscopicity, and their ability to act as cloud condensation nuclei (CCN) and ice nuclei (IN). All these properties are highly variable in space scales and timescales due to aerosol particles' short-lived, nonuniform emissions and the dependence of sinks on meteorology (Randall et al., 2007). Thus, the determination of atmospheric aerosol properties, by a complex interplay between their sources, atmospheric transformation processes and their removal from the atmosphere (Boucher et al., 2013), plays a part in the large uncertainty of aerosol effects on the Earth's climate.

It was in the 1980s when the atmospheric science community began to pay increasing attention to the atmospheric aerosol subject (Fuzzi et al., 2015). Since then, major efforts have been made to acquire better knowledge of atmospheric aerosol properties and their interactions with the Earth's climate to reduce the abovementioned large uncertainty. Many regional field measurement campaigns have taken place; e.g., the Integrated Campaign for Aerosols, Gases and Radiation Budget (ICARB; Moorthy et al., 2008); the Megacity Impact on Regional and Global Environments field experiment (MILAGRO; Paredes-Miranda et al., 2009); the Integrated Project on Aerosol Cloud Climate and Air Quality interactions (EUCAARI; Kulmala et al., 2011); Aerosol, Radiation, and Cloud Processes affecting Arctic Climate (ARCPAC; Warneke et al., 2010); among many others (Boucher et al., 2013). Moreover, global long-term aerosol measurements are taken by surface networks, such as Global Atmosphere Watch (GAW; Ogren, 2011), Aerosol Robotic Network (AERONET; Holben et al., 1998), the European Monitoring and Evaluation Programme (EMEP; Tørseth et al., 2012) or by satellite sensors, such as the Moderate Resolution Imaging Spectroradiometer (MODIS; Remer et al., 2005) or the Cloud-Aerosol Lidar and Infrared Pathfinder Satellite Observation (CALIPSO; Winker et al., 2003) among many other base measurements, base networks and instruments aboard satellites (Boucher et al., 2013).

Measurements provide incomplete sampling but can be combined with information from global and regional models. There is a large number of international initiatives that study, among other climate issues, atmospheric aerosols and their climatic effects. Some examples are the Aerosol Compar- isons between Observations and Models project, now in their phase II (AEROCOM-II; Schulz et al., 2009), the Coupled Model Intercomparison Project, now in phase 6 (CMIP6; Eyring et al., 2016), the Chemistry-Climate Model Initiative (CCMI; Eyring et al., 2013) or the Aerosol and Chemistry Model Intercomparison Project (AerChemMIP; Collins et al., 2017). Among these initiatives, the primary purpose of the Air Quality Modelling Evaluation International Initiative (AQMEII; Rao et al., 2011) is to coordinate international efforts in scientific research on regional air quality model evaluations across the modeling communities of North America and Europe.

AQMEII Phase 1 (Galmarini et al., 2012) focused on developing general model-to-model and modelto-observation evaluation methodologies, while Phase 2 (Galmarini et al., 2015) focused on simulating aerosolclimate feedbacks with online coupled modeling systems. As part of Phase 2, some studies evaluated aerosol properties and their effects on the climate system. Balzarini et al. (2015) analyzed online model sensitivity to the chemical mechanisms of WRF-Chem chemistry-meteorology coupled model when reproducing aerosol properties; results found that although different chemical mechanisms gave different aerosol optical depths (AODs), it was commonly underestimated. Forkel et al. (2015) found pronounced feedback effects, such as a reduction in seasonal mean solar radiation of $20 \mathrm{Wm}^{-3}$ and temperature of $0.25^{\circ}$ in the summer of 2010, when ARIs were considered. High aerosol concentrations resulted in a $10 \%-30 \%$ decreased precipitation and low concentrations in very low cloud droplet numbers (5-100 droplets $\mathrm{cm}^{-1}$ ) and a $50 \%-70 \%$ lower cloud liquid water, which led to an increase in downward solar radiation of almost $50 \%$ when ACIs were taken into account. Makar et al. (2015) evaluated the effect on chemistry due to the feedback between aerosols and meteorology. In this study, ACIs were usually found to have a strong effect on ozone, particulate matter and other species, and also on the atmospheric transport and chemistry of large emitting sources such as plumes from forest fires and large cities. A similar work is that of Wang et al. (2015), in which a multimodel assessment of major column abundances of gases, radiation, aerosol and cloud variables was made using available satellite data. The evaluation results showed an excellent agreement between all the simulations and satellite-derived radiation variables, as well as precipitable water vapor. Other aerosol-/cloudrelated variables, such as AOD, cloud optical thickness, cloud liquid water path, $\mathrm{CCN}$ and cloud droplet number concentration were moderately to largely underestimated by most simulations due to underestimations in aerosol loadings (Baró et al., 2018). These authors also highlighted the large uncertainties associated with current model treatments of ACIs.

Moreover, and through AQMEII Phase 2, working group 2 of the COST Action ES1004 EuMetChem (European framework for online integrated air quality and meteo- 
rology modeling; http://www.eumetchem.info/, last access: 10 October 2017) investigated the importance of different processes and feedbacks in online coupled chemistrymeteorology/climate models for air quality simulations and weather predictions. As part of this initiative, an important aerosol load episode, the Russian wildfires in 2010, was investigated. Results indicated that the inclusion of ARIs led to a drop between 10 and $100 \mathrm{Wm}^{-2}$ in the average downward shortwave radiation on the ground and an almost $1^{\circ}$ in the mean temperature (Forkel et al., 2016; Toll et al., 2015a). During the same episode, Baró et al. (2017) found a reduction in the $10 \mathrm{~m}$ wind speed of $0.2 \mathrm{~ms}^{-1}(10 \%)$ because the presence of biomass burning aerosols implied a reduction in shortwave downwelling radiation on the surface which, in turn, led to a reduction in the $2 \mathrm{~m}$ temperature. Thus, it led to a reduction in the turbulence flux and developed a stabler planetary boundary layer. Kong et al. (2015) and PalaciosPeña et al. (2018) evaluated the effects of the inclusion of ARIs and ACIs for this 2010 wildfire episode and a desert dust outbreak. These results showed that a minor, but significant, improvement was observed when ARIs and ACIs were taken into account.

AQMEII Phase 3, to which this work contributes, focused on evaluating and intercomparing regional and coupled global/regional modeling systems by collaborating with the Task Force on Hemispheric Transport of Air Pollution Phase 2 (HTAP2; Dentener et al., 2015). The simulation strategy followed the procedure adopted in the first two AQMEII phases, as described in Galmarini et al. (2012, 2015, 2017).

On the other hand, several previous studies evaluated modeled aerosol optical properties against satellite data from a global point of view. In Ghan et al. (2001), simulated AODs were within a factor of 2 with respect to AVHRR (Advanced Very High Resolution Radiometer) products and the behavior of the Ångström exponent (AE), estimated from POLDER (POLarization and Directionality of the Earth's Reflectances) and SeaWiFS (Sea-viewing Wide Field-of-view Sensor), was similar to that simulated. Otherwise, both the simulated AODs in Chin et al. (2002) and Reddy et al. (2005) were reproduced with most of the notable features in TOMS (Total Ozone Mapping Spectrometer), AVHRR and MODIS. Moreover, Ginoux et al. (2006) revealed sensitivity to humidity when evaluating modeling results against satellite data. Kinne et al. (2003) compared aerosol modules from seven models with MODIS and TOMS, and found large discrepancies over tropical and Southern Hemisphere oceans due to the sea salt treatment. Kinne et al. (2006) also discovered a lower simulated AOD among 20 different modules from the AEROCOM project ( 0.11 to 0.14 ) when comparing simulations with the satellite AOD composite of MODIS, MIRS (Microwave Integrated Retrieval System), AVHRR, TOMS and POLDER retrievals (0.15).

More recent studies are Colarco et al. (2010), who assessed simulated AOD versus MODIS and MIRS, and found similar seasonal and regional variability and magnitude downwind of the Saharan dust plume, a high bias in sulfatedominated regions of North America and Europe, and a better agreement over ocean when the sea salt burden was reduced by a factor of 2 . Furthermore, Zhang et al. (2012) reported a relative difference in $\mathrm{AE}$ of $13.8 \%$ with a negative (positive) bias over high-latitude regions (oceans) but a good correlation for AOD in comparison with MODIS. Finally, Liu et al. (2012) evaluated long-term simulations compared with the satellite composite derived by Kinne et al. (2006) and identified a low bias for AOD but a good representation of the observed geographical and temporal variations of aerosol optical properties.

Similar studies to the one presented in this contribution are those of Jeuken et al. (2001), who made a seasonal comparison (over Europe) of AOD calculations with ATSR-2 (Along-Track Scanning Radiometer 2) aboard the European ERS-2 satellite. The results showed an average difference of $0.17-0.19$ but a good representation of the observed patterns. Simulated AOD in Solmon et al. (2006) presented a general underestimation (more pronounced over the Mediterranean Basin), but within the range of AERONET and MIRS over northern Europe, and common spatial patterns to those of MODIS and TOMS over both Europe and Africa.

Recently, Curci et al. (2019) used AQMEII Phase 3 simulations to evaluate black carbon absorption against AERONET, but no works have evaluated the modeled seasonal representation of optical properties against satellite observations over Europe with the variety of regional models involved in AQMEII Phase 3. This represents an added value of the current contribution because (1) all the regional models evaluated here were run using the same boundary and initial conditions, which permits us to investigate the importance of different processes and feedbacks in each model; (2) the use of two different emissions datasets allows the evaluation of the influence of these emissions in the representation of aerosol optical properties; and (3) the use of online coupled chemistry-meteorology/climate models (as some of the models used here) permits the investigation of the influence of ARIs and ACIs. As mentioned above, aerosol optical properties influence ARIs and ACIs, and hence a good representation of them is thus a key issue to reduce the uncertainty of aerosol effects on the Earth's climate system. For this reason, our main aim was to evaluate the representation of two fundamental aerosol optical properties, AOD and AE, using the models included in the AQMEII Phase 3 initiative over Europe. The evaluation was made by using remote-sensing observations from the MODIS sensor and from AERONET and MAN (Maritime Aerosol Network). Section 2 provides a brief description of the observations and models, and the evaluation methodology. Section 3 presents and discusses the evaluation results. Finally, Sect. 4 summarizes the main conclusions reached. 


\section{Methodology}

In this work, we focused on evaluating the representation of aerosol optical properties (AOD and AE) over Europe throughout the year 2010. The evaluation was conducted using remote-sensing data from the MODIS sensors aboard the Terra and Aqua satellites, and AERONET and MAN groundbased networks.

\subsection{Model simulations}

The evaluated simulation data were taken from the regional chemistry-meteorology simulations made over Europe within the framework of the AQMEII Phase 3 initiative.

Two different anthropogenic emissions datasets were used. One of these was HTAP_v2.2 (referred to from this point onwards as HTAP emissions). These data were harmonized by the Joint Research Centre's (JRC) Emissions Database for Global Research (EDGAR) team in collaboration with regional emission experts from different agencies from the United States, Europe and Asia. HTAP emissions covered the years 2008 and 2010, with yearly and monthly time resolutions, and a global geocoverage with a spatial resolution of $0.1^{\circ}$. The chemical species were $\mathrm{SO}_{2}, \mathrm{NO}_{x}, \mathrm{NMVOC}$, $\mathrm{CH}_{4}, \mathrm{CO}, \mathrm{NH}_{3}, \mathrm{PM}_{10}, \mathrm{PM}_{2.5}, \mathrm{BC}$ and $\mathrm{OC}$ at the sectorspecific level. There were seven emission sectors included (air, ships, energy, industry, transport, residential and agriculture) (Janssens-Maenhout et al., 2015; Galmarini et al., 2017).

On the other hand, the Monitoring Atmospheric Composition and Climate (MACC) emissions (Pouliot et al., 2015) were used. MACC was previously used for AQMEII Phase 2 (Galmarini et al., 2015). The dataset is a follow-on to the widely used TNO-MACC database (Pouliot et al., 2012), with a base resolution of $\sim 7 \mathrm{~km}$. The provided species were $\mathrm{CH}_{4}, \mathrm{CO}, \mathrm{NO}_{x}, \mathrm{SO}_{x}, \mathrm{NMVOC}, \mathrm{NH}_{3}, \mathrm{PM}_{\text {coarse }}$ and $\mathrm{PM}_{2.5}$. A separate PM bulk composition profile file was composed, based on information per source sector and per country. The different represented chemical components were EC, OC, $\mathrm{SO}_{4}^{-2}$, sodium and other mineral components. For all the AQMEII Phase 3 participants, wildfire emissions were included as in Pouliot et al. (2015) and Soares et al. (2015) but volcanic and dimethyl sulphide (DMS) emissions were not considered (Galmarini et al., 2017).

The study period was 2010 and the target domain was Europe. A detailed description of the simulations can be found in Solazzo et al. (2017). However, a brief summary focused on aerosol treatment is provided below and summarized in Table 1.

The FI1 simulations were run at the Finnish Meteorological Institute (FMI), and the only difference between both FI1 simulations was the type of emissions used (HTAP or MACC). The System for Integrated modeling of Atmospheric coMposition (SILAM), version 5.4. (Sofiev et al., 2015), was run with the meteorological input extracted from the European Centre for Medium-Range Weather Forecasts (ECMWF). Sea salt emissions were included as in Sofiev et al. (2011) (but not for boundaries), and biogenic volatile organic compound (VOC) emissions were taken from Poupkou et al. (2010). Wind-blown dust was included only from lateral boundary conditions. Gas-phase chemistry was simulated with Carbon Bond Mechanism IV (CBM-IV) and with updated reaction rates according to IUPAC (http://iupac. pole-ether.fr, last access: 27 September 2017) and JPL (https: //jpldataeval.jpl.nasa.gov, last access: 27 September 2017) recommendations. Secondary inorganic aerosol (SIA) formation was computed with the updated Dispersion Model of Atmospheric Transport (DMAT) scheme (Sofiev, 2000) and secondary organic aerosol (SOA) formation with the volatility basis set (VBS; Donahue et al., 2006). AOD in SILAM was calculated assuming external mixture of spherical particles, taking into account their hygroscopic growth. The optical properties used in the Mie computations come from the OPAC dataset (Hess et al., 1998).

The ES1 simulation was run by the Regional Atmospheric Modelling Group at the University of Murcia (UMU, Spain). They used the Weather Research and Forecasting model online coupled with chemistry (WRF-Chem; Grell et al., 2005), version 3.6.1. Meteorological inputs were driven by ECMWF analysis fields. The aerosol module was the Modal Aerosol Dynamics model for Europe (MADE; Ackermann et al., 1998), in which secondary organic aerosols (SOAs) were incorporated by using the Secondary Organic Aerosol Model (SORGAM; Schell et al., 2001). The gas-phase chemistry mechanism was the Regional Acid Deposition Model version 2 (RADM2; Stockwell et al., 1990), with 57 chemical species and 158 gas-phase reactions, among which 21 are photolytic. Anthropogenic emissions were MACC emissions. Biogenic VOC emissions were computed by applying the Model of Emissions of Gases and Aerosols from Nature (MEGAN) emissions model (Guenther, 2006), version 2.04. The MADE/SORGAM sea salt (Gong, 2003) and dust (Shaw et al., 2008) emissions were used.

The IT1 simulation was conducted at Ricerca sul Sistema Energetico (RSE; Italy) using the WRF model coupled with the Comprehensive Air Quality Model with Extensions (CAMx), version 6.10. Meteorological inputs were generated using WRF version 3.4.1. Anthropogenic emissions were MACC and biogenic emissions were estimated by MEGAN. WRF-Chem was adopted to predict GOCART (Goddard Chemistry Aerosol Radiation and Transport) dust emissions (Ginoux et al., 2001) along with meteorology. Sea salt emissions were computed using de Leeuw et al. (2000) and Gong (2003) methodologies. The WRF-CAMx preprocessor (version 4.2; ENVIRON, 2014) was used to create the CAMx ready input files by collapsing the 33 vertical layers used by WRF to 14 layers in CAMx but maintaining the layers identical up to $230 \mathrm{~m}$ above ground level. Aerosol optical properties were estimated by means of the Aerosol Optical DEpth Module (AODEM; Landi, 2013) postprocessing tool 
that was coupled to the CAMx regional model. AODEM calculated the optical properties (e.g., AOD, extinction and scattering coefficients, and particle number concentrations) at different wavelengths and size bins starting from the aerosol mass concentration predicted by CAMx. In this work, the Mie theory was applied by dividing the size range $(40 \mathrm{~nm}$ to $10 \mu \mathrm{m})$ into 10 bins and calculating the hygroscopic growth of each aerosol species in each bin with the Hanel formula. Moreover, particles were assumed to be internally mixed.

The IT2 simulations were run at the University of L'Aquila (Italy) using WRF-Chem (Grell et al., 2005), version 3.6. The modified MADE/VBS aerosol scheme (Tuccella et al., 2015) was included in this version. This scheme is based on MADE to treat inorganic aerosols along with the VBS approach (Ahmadov et al., 2012). MADE/VBS allows a better representation of the SOA mass. The Regional Atmospheric Chemistry Mechanism - Earth System Research Laboratory (RACM-ESRL) gas-phase chemical mechanism (Kim et al., 2009) was used. Anthropogenic emissions were MACC emissions, adapted to the chemical mechanism used following the method of Tuccella et al. (2012). As for the IT1 and ES1 simulations, biogenic emissions were calculated online by the MEGAN model (Guenther, 2006). Finally, the meteorological analyses used to initialize WRF were provided by the ECMWF with a horizontal resolution of $0.5^{\circ}$ every 6 h. IT2_M-ARI was run with ARIs, while large-scale clouds were solved by a simple module. IT2_M-ARI+ACI took into account ARIs and ACIs, while aqueous chemistry was solved in convective clouds. As for ES1, IT2 simulations used the MADE/SORGAM sea salt and dust emissions.

WRF-Chem simulations (ES1 and IT2) calculated aerosol optical properties according to wavelength following Fast et al. (2006), Chapman et al. (2009) and Barnard et al. (2010). The composite aerosol optical properties were determined by the Mie theory, adding over all size bins and wet particles diameters. An overall refractive index for a given size bin, as determined by a volume averaging, assuming an internal mixing, of complex indexes of refraction associated with each chemical constituent of the aerosol, was used. The inclusion of ACIs and ARIs in WRF-Chem is described in Chapman et al. (2009).

A multimodel ensemble (henceforth referred to as ENSEMBLE) of the available simulations was also evaluated. The results presented herein did not intend to represent an ensemble of opportunity but were merely calculated as the mean of all the participating simulations. As part of the AQMEII Phase 3 initiative, the available variables of aerosol optical properties were AODs at 470, 550 and $675 \mathrm{~nm}$.

\subsection{Observational data}

The observational data used were obtained from the twin MODIS (Moderate Resolution Imaging Spectroradiometer) sensors. These instruments, aboard the Terra (MOD04_L2) and Aqua (MYD04_L2) satellites, provide information about aerosol optical properties around the world. Moreover, in order to conduct a reliable and complete analysis, we used ground-based observations from all the available stations in AERONET (https://aeronet.gsfc.nasa.gov/, last access: 18 October 2017) and the available data from the MAN (https://aeronet.gsfc.nasa.gov/new_web/maritime_ aerosol_network.html, last access: 25 May 2018) which is a component of AERONET.

MODIS data came from level 2 of the atmospheric aerosol product (both MOD04_L2 and MYD04_L2) from collection 6 (C6), with a resolution of $10 \mathrm{~km}$. These data were estimated by two different algorithms, Dark Target (DT) and Deep Blue (DB). The used variables were (1) a "combined" variable of the DT and DB algorithms which provide information about $\mathrm{AOD}$ at $550 \mathrm{~nm}$ for both ocean and land, and (2) AE between 550 and $860 \mathrm{~nm}$ over the ocean estimated by the DT algorithm. There are several evaluations of these "combined" AOD products of MODIS C6 against AERONET sites around of the world (Sayer et al., 2014; Mhawish et al., 2017; Bilal et al., 2018). All of these established that a high percentage of retrievals are within the estimated error (EE) of the DT and DB algorithms, which is $( \pm 0.05+15 \%)$ (Levy et al., 2013). Moreover, in Sayer et al. (2014) and Bilal et al. (2018), the performance of combined retrievals outperformed DT or DB retrievals in terms of correlation (around 10\%); meanwhile, they showed relative mean bias values similar at a global scale. The preliminary $\mathrm{EE}$ for the used $\mathrm{AE}$ product was 0.45 in the pixels with an AOD $>0.2$ (Levy et al., 2013). The selection of this observational data was based on results found by PalaciosPeña et al. (2018). These authors evaluated the uncertainty in the satellite estimates by comparing MODIS, OMI (Ozone Monitoring Instrument) and SeaWiFS AOD retrievals against AERONET observations. They found that MODIS presented the best agreement with the AERONET observations compared to other satellite AOD observations during two studies with high aerosol load during 2010 over Europe.

As Terra and Aqua are in Sun-synchronous orbits around the Earth, MODIS does not provide data over the entire studied domain for each time step. According to Levy et al. (2013), who have established that there is no significant difference between MODIS/AERONET comparability for Terra and Aqua data, we combined the hourly data from both satellites in order to obtain a whole year of data with a wider coverage for each time step than by using the Terra and Aqua data separately.

AODs at $675 \mathrm{~nm}$ and AE between 440 and $870 \mathrm{~nm}$ retrievals from AERONET level 2.0 from the available European stations during the entire year 2010 were used. In the case of this network, the total uncertainty for the AOD data under cloud-free conditions is established as $< \pm 0.01$ for $\lambda>440 \mathrm{~nm}$ and $< \pm 0.02$ for shorter wavelengths (Holben et al., 1998). The same variables were used from MAN, which provided instantaneous ship-borne aerosol optical depth measurements. MAN-estimated uncertainty of AOD in 
Table 1. Model simulations.

\begin{tabular}{|c|c|c|c|c|c|c|c|c|}
\hline $\begin{array}{l}\text { Model } \\
\text { Code }\end{array}$ & $\begin{array}{l}\text { Insti- } \\
\text { tution }\end{array}$ & $\begin{array}{l}\text { Meteorolo- } \\
\text { gical model }\end{array}$ & $\begin{array}{l}\text { Dispersion } \\
\text { model }\end{array}$ & $\begin{array}{l}\text { Emi- } \\
\text { ssions }\end{array}$ & $\begin{array}{l}\text { Aerosol mech. } \\
\text { (dust sources) }\end{array}$ & $\begin{array}{l}\text { AOD/AE } \\
\text { estimation }\end{array}$ & $\begin{array}{l}\text { Gas-phase } \\
\text { mech. }\end{array}$ & $\begin{array}{l}\text { Resolution } \\
(X Y, Z)^{*}\end{array}$ \\
\hline FI1_HTAP & \multirow[t]{2}{*}{ FMI } & \multirow[t]{2}{*}{ ECMWF } & \multirow{2}{*}{$\begin{array}{l}\text { SILAM } \\
\text { v.5.4. }\end{array}$} & HTAP & \multirow{2}{*}{$\begin{array}{l}\text { DMAT } \\
\text {-VBS } \\
\text { (boundaries) }\end{array}$} & \multirow{2}{*}{$\begin{array}{l}\text { Prognostic/ } \\
\text { diagnostic }\end{array}$} & \multirow[t]{2}{*}{ CBM-IV } & $0.25^{\circ}$ \\
\hline FI1_MACC & & & & MACC & & & & $\begin{array}{l}12 \text { uneven levs. } \\
\text { below } 13 \mathrm{~km} \\
\text { (first to } \sim 30 \mathrm{~m} \text { ) }\end{array}$ \\
\hline ES1_MACC & UMU & WRF & $\begin{array}{l}\text { WRF-Chem } \\
\text { v3.6.1 }\end{array}$ & MACC & $\begin{array}{l}\text { MADE- } \\
\text { SORGAM } \\
\text { (online }+ \\
\text { boundaries) }\end{array}$ & $\begin{array}{l}\text { Prognostic/ } \\
\text { diagnostic }\end{array}$ & RADM2 & $\begin{array}{l}23 \mathrm{~km} \text {, } \\
33 \text { levs. } \\
\text { up to } 50 \mathrm{hPa} \\
\text { (first to } \sim 21 \mathrm{~m} \text { ) }\end{array}$ \\
\hline IT1_MACC & RSE & WRF & $\begin{array}{l}\text { CAMx } \\
\text { v. } 3.4\end{array}$ & $\begin{array}{l}\text { MACC } \\
\text { v6.10 }\end{array}$ & $\begin{array}{l}\text { Coarse- } \\
\text { fine } \\
\text { (online }+ \\
\text { boundaries) }\end{array}$ & Diagnostic & CB05 & $\begin{array}{l}23 \mathrm{~km}, \\
14 \text { levs. } \\
\text { up to } 8 \mathrm{~km} \\
\text { (first to } \sim 25 \mathrm{~m} \text { ) }\end{array}$ \\
\hline IT2_M-ARI & \multirow[t]{3}{*}{ UAq } & \multirow[t]{3}{*}{ WRF } & \multirow{3}{*}{$\begin{array}{l}\text { WRF-Chem } \\
\text { v3.6 }\end{array}$} & \multirow[t]{3}{*}{ MACC } & (ARIs) & \multirow{3}{*}{$\begin{array}{l}\text { Prognostic/ } \\
\text { diagnostic }\end{array}$} & & $23 \mathrm{~km}$ \\
\hline $\begin{array}{l}\text { IT2_M- } \\
\text { ARI+ACI }\end{array}$ & & & & & $\begin{array}{l}\text { MADE/VBS } \\
(\mathrm{ARI}+\mathrm{ACI})\end{array}$ & & $\begin{array}{l}\text { RACM- } \\
\text { ESRL }\end{array}$ & $\begin{array}{l}33 \text { levs. } \\
\text { up to } 50 \mathrm{hPa}\end{array}$ \\
\hline & & & & & $\begin{array}{l}\text { (online }+ \\
\text { boundaries) }\end{array}$ & & $\begin{array}{l}\text { (Aq. conv. } \\
\text { clouds) }\end{array}$ & $\begin{array}{l}12 \text { below } 1 \mathrm{~km} \\
\text { (first to } \sim 12 \mathrm{~m} \text { ) }\end{array}$ \\
\hline
\end{tabular}

FMI (Finnish Meteorological Institute, Finland), UMU (University of Murcia, Spain), RSE (Ricerca sul Sistema Energetico, Italy), UAq (University of L'Aquila, Italy).

* $X Y$ : horizontal resolution; $Z$ : vertical resolution.

Table 2. MAN period of measurements during the year 2010.

\begin{tabular}{|c|c|c|c|c|}
\hline Boat & JFM & AMJ & JAS & OND \\
\hline Alliance & & & 20 Aug-3 Sep & \\
\hline Ak Fedorov & & 6-10 May & & 23-24 Nov \\
\hline Ak Ioffe & & & 13-19 Sep & \\
\hline James Cook & & & & 17-18 Oct \\
\hline Oceania & & 8 Apr-14 Jun & 17-21 Aug & \\
\hline Polarstern & & 5-15 May & & 25 Oct -8 Nov \\
\hline Zim Iberia & & 15-19 May & & \\
\hline
\end{tabular}

each channel is, as for AERONET, $< \pm 0.02$ because MAN is affiliated with the AERONET calibration and data processing standards and procedures (Smirnov et al., 2009). Table 2 lists those time periods when the MAN data were available for our study.

\subsection{Evaluation method}

Simulations (Table 1) and observed data had a different spatial resolution. Henceforth and beforehand, all the gridded data (simulations and satellite) were preprocessed and bilinearly interpolated to a common working grid with a horizontal resolution of $0.25^{\circ}$.

As previously mentioned, our objective was to evaluate the representation of the main aerosol optical properties: AOD and AE. Observed optical properties were not available in the same wavelengths as simulations. Thus, in order to evaluate $\mathrm{AE}$ from simulations, this variable had to be estimated through the Angström empirical expression (Eq. 1; Angström, 1929), where $\lambda$ is the wavelength and $\beta$ is Ångström's turbidity coefficient.

$$
\mathrm{AOD}=\beta \lambda^{-\mathrm{AE}}
$$

By partitioning Eq. (1) at two different wavelengths and taking algorithms, AE can be computed from the spectral AOD values (Eq. 2; Eck et al., 1999). Hence, it is possible to estimate AE between two known wavelengths and to also use this AE to estimate AOD at other different wavelengths. However, as established in Ignatov et al. (1998), retrievals of AE under AOD conditions lower than 0.1 are highly uncertain. For this reason, we chose the criteria to estimate AE over areas with AOD $>0.1$. Moreover, and according to the $\mathrm{EE}$ for the AE products of MODIS, we set the AE values range between -0.5 and 4.0. It is widely known that $\mathrm{AE}$ values spread from 0 to 4 and even sometimes, when really coarse particles are presented, they can reach negative values. Hence, we chose AE values with -0.5 as the lowest limit in order to cover possible negative values in a close smoothing value to the EE for the AE products of MODIS.

$$
\mathrm{AE}=-\frac{\ln \left(\frac{\mathrm{AOD}_{\lambda_{2}}}{\mathrm{AOD}_{\lambda_{1}}}\right)}{\ln \left(\frac{\lambda_{2}}{\lambda_{1}}\right)}
$$


All the observations used in this work are not provided temporally in a regular way. This means that the number of occurrences in each of the pixels for satellite data or in each AERONET station were not the same. As the results in this work are shown as seasonal means and in order to show robust means estimated with a reasonable number of occurrences (as in Palacios-Peña et al., 2018), a mask containing those pixels (stations) where the satellite (station) occurrences were higher than the $10 \%$ of the maximum possible occurrences, was implemented. The total coverage of accurate satellite products is limited by the application of different algorithms which apply physical theory and the mathematical procedures to convert the radiances measured by the instruments to geophysical quantities (as the ones used in https://modis.gsfc.nasa.gov/data/, last access: 18 October 2017). In this sense, the total number of accurate satellite products does not represent the total radiance measures, and therefore the maximum of possible occurrences for satellite data was selected as the maximum of occurrences during each studied season (JFM, AMJ, JAS or OND) over the entire domain. On the other hand, AERONET provides long-term and continuous data; thus, the maximum of possible occurrences was established as the maximum of solar-light hours, because of the use of Sun photometers, in each station during each season. Figure 1 shows the number of total observations and the number of observations used when the mask was implemented. This mask was not implemented in MAN data because this network portrays instantaneous data.

Once all the data had the same spatial and temporal resolution, and following Eq. (2), the simulated AOD and AE were calculated at the observed wavelengths. Then, the hourly data were evaluated using classical statistics such as the mean of the individual model-prediction error or bias $\left(e_{\mathrm{i}}\right)$, the mean bias error (MBE), the mean of the absolute error (MAE) and the coefficient of determination $(r)$, according to Willmott et al. (1985), Weil et al. (1992) and Willmott and Matsuura (2005). It is widely known that AERONET and MAN provide punctual observations; thus, simulation values for the evaluation against these networks were extracted by using the nearest neighbor approach.

The MBE was estimated as in Eq. (3), where $i$ represents each time step, $P$ is the simulation data, and $O$ is the observational value. MBE provides an idea about the behavior of the models and indicates whether the model over- or underestimates the variable measured by the satellite sensor.

$\mathrm{MBE}=n^{-1} \sum_{i=1}^{n} e_{\mathrm{i}}=\overline{P_{i}-O_{i}}$
The MAE was calculated as in Eq. (4) and provides an estimation of the magnitude of the error independently of overor underestimation.

MAE $=\left\langle n^{-1} \sum_{i=1}^{n}\left|e_{\mathrm{i}}\right|\right\rangle=\overline{\left|P_{i}-O_{i}\right|}$

The temporal determination coefficient was estimated as in Eq. (5) and was used as a measure of the strength of the linear relationship between two variables - in our case, the satellite and simulations values.

$r^{2}=\left\langle\frac{n^{-1} \sum_{i=1}^{n}\left(O_{i}-\bar{O}\right)\left(P_{i}-\bar{P}\right)}{\sigma_{O} \sigma_{P}}\right\rangle^{2}$

Finally, the kernel probability density functions (PDFs) with a broadband of 0.05 were used to evaluate the skills of the simulations to reproduce the spatiotemporal variability of the target variables (AOD and $\mathrm{AE}$ ).

\section{Results}

This section evaluates the skills of the different AQMEII Phase 3 simulations regarding AOD and AE. The first section shows the model evaluation for AOD and the second for AE. The numerical results of each case for MODIS (M) and AERONET (A) are indicated by the numbers represented in each figure. Simultaneously, these results were listed in Tables S1, S2, S3 and S4 in the Supplement. Finally, the skills of the simulations to reproduce the variability of AOD and $\mathrm{AE}$ are analyzed using the $\mathrm{PDF}$ of each variable.

\subsection{Model evaluation of the AOD representation}

AOD is defined as the integrated extinction coefficient over a vertical atmospheric column and indicates to what degree aerosols avoid light transmission. AOD is not a direct function of the atmospheric load of particles but can provide us an approximate idea of both atmospheric load of particles and the interaction of these particles with radiation.

The top rows in Figs. 2, 3 and 4 show the temporal means of AOD at $550 \mathrm{~nm}$ values from a combination of the two MODIS satellites and of AOD at $675 \mathrm{~nm}$ from AERONET stations. MAN data are displayed as diamonds linked by a colored line. Each color represents the track of each ship and accounts for instantaneous observations. The seasonal means and corresponding MAN data are presented in columns. JFM represents the temporal mean for January, February and March (from now on, winter); AMJ for April, May and June (spring); JAS for July, August and September (summer); and finally, OND for October, November and December (autumn).

When seasonal figures were analyzed (Figs. 2, 3 and 4), the highest values (around 1) were found over the southern 


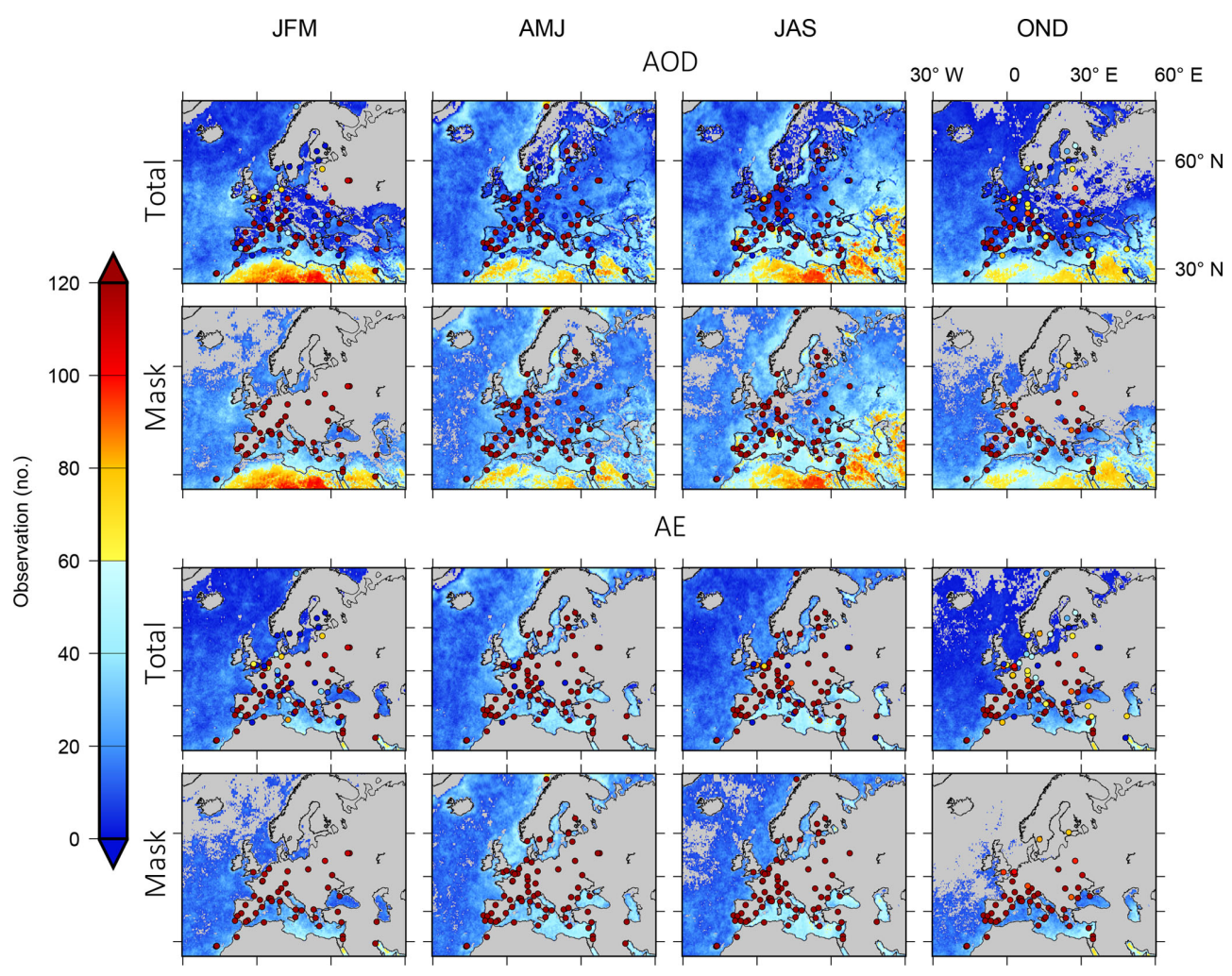

Figure 1. Total and under-the-mask number of observations used in the analysis. Maps show the number of MODIS observations and point out the number of AERONET observations.

part of the domain for all seasons due to frequent Saharan desert dust outbreaks, impacting the Mediterranean region. Moreover, these desert dust outbreaks were more frequent and stronger for spring and summer over the southern part of the domain with mean AOD values above 0.4. In summer, the highest mean AOD values (above 1 for MODIS values) were found over a large area in Russia and its surrounding areas due to the heatwave and wildfires occurring over this area in 2010. However, in autumn and winter, high mean AOD values were also found over the southern part of the domain but were lower than 0.4. The lowest mean AOD value when considering space and time was found in autumn. It is noteworthy that AOD satellite values strongly agree with values by the available AERONET stations and MAN data. The gap in the satellite observations over the northern part of the land domain in winter and autumn is explained because ice, snow and clouds were avoided for the MODIS sensor, and aerosol properties were not retrieved over those areas (https://darktarget.gsfc.nasa.gov/, last access: 18 October 2017). The gap in the rest of the seasons is explained by the limited number of observations (implemented mask explained in the observational data section). Moreover, as the number of solar-light hours is lower in the north during winter and autumn, this affected also the number of AERONET stations with available data. It explains the lack of AERONET data because the criterion applied (number of occurrences equal to or higher than $10 \%$ of the maximum of solar hours) was not met in a large number of AERONET stations. Throughout the seasons, high AOD values were obtained over the southeastern part of the domain, outside Europe: Syria, Iraq, Kuwait and the Persian Gulf.

For the MBE, all the simulations presented (spatially) a similar behavior in different seasons (Fig. 2). The main common feature of the models was an overestimation of AOD over the southern part of the domain (the main area affected by desert dust outbreaks), and an underestimation to a greater or lesser extent - over Russia, affected by the wildfire emissions in summer. It is remarkable that the results are similar when the evaluation is made against MODIS or AERONET. On certain occasions, mean spatiotemporal MBE was lower for the assessment versus AERONET data (maybe because AERONET stations provided punctual data and could not be located near the areas with larger problems in the representation of AOD). MAN results could not be similar to MODIS and AERONET, since instantaneous data were used for the evaluation and not temporal means (as done for MODIS and AERONET).

As a general behavior during all the seasons, FI1_HTAP and FI1_MACC, which use the ECMWF model for meteorology and SILAM for chemistry, showed a slight overestimation of AOD and higher AOD values than the rest of the models. This may be caused by the slower dry particle depo- 


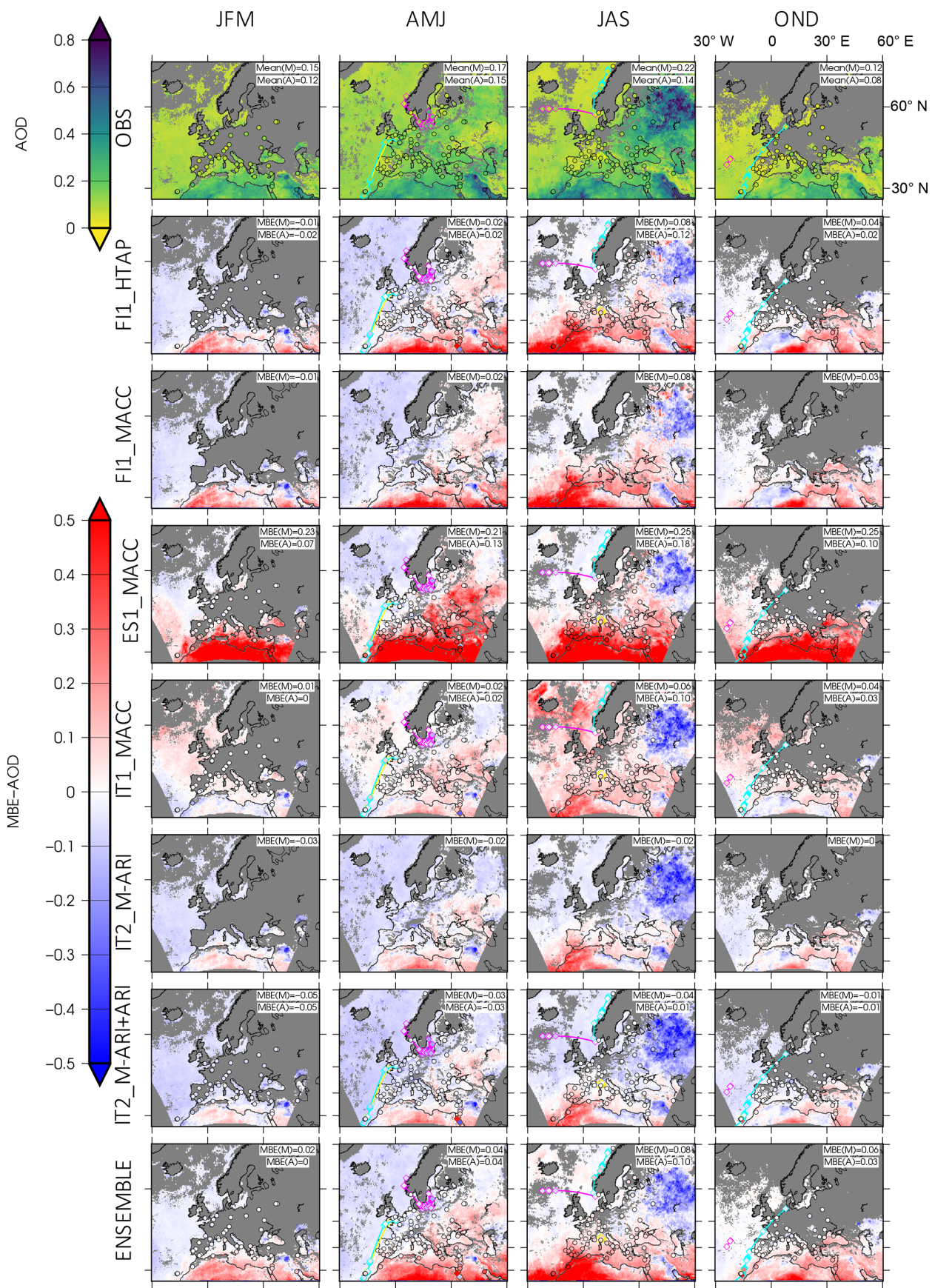

Figure 2. MBE results of AOD at $550 \mathrm{~nm}$ from satellite (maps) and AOD at $675 \mathrm{~nm}$ from AERONET (points) and MAN (colored diamond) values versus simulations at the same wavelengths. Columns from left to right, temporal mean of winter (JFM), spring (AMJ), summer (JAS) and autumn (OND). First row: observations; from second row to the bottom: MBE values of FI1_HTAP, FI1_MACC, ES1_MACC, IT1_MACC, IT2_M-ARI, IT2_M-ARI+ACI and ENSEMBLE. Bonded lines between diamonds represent the ship track during AMJ: $A k$ Fedorov (yellow), Oceania (magenta), Polarstern (cyan) and Zim Iberia (chocolate); JAS: Alliance (yellow), Ak Ioffe (magenta) and Oceania (cyan); and OND: Ak Fedorov (yellow), James Cook (magenta) and Polarstern (cyan). Values in every plot indicate the spatial and temporal average of MBE for MODIS (MBE(M)) and AERONET (MBE(A)). 

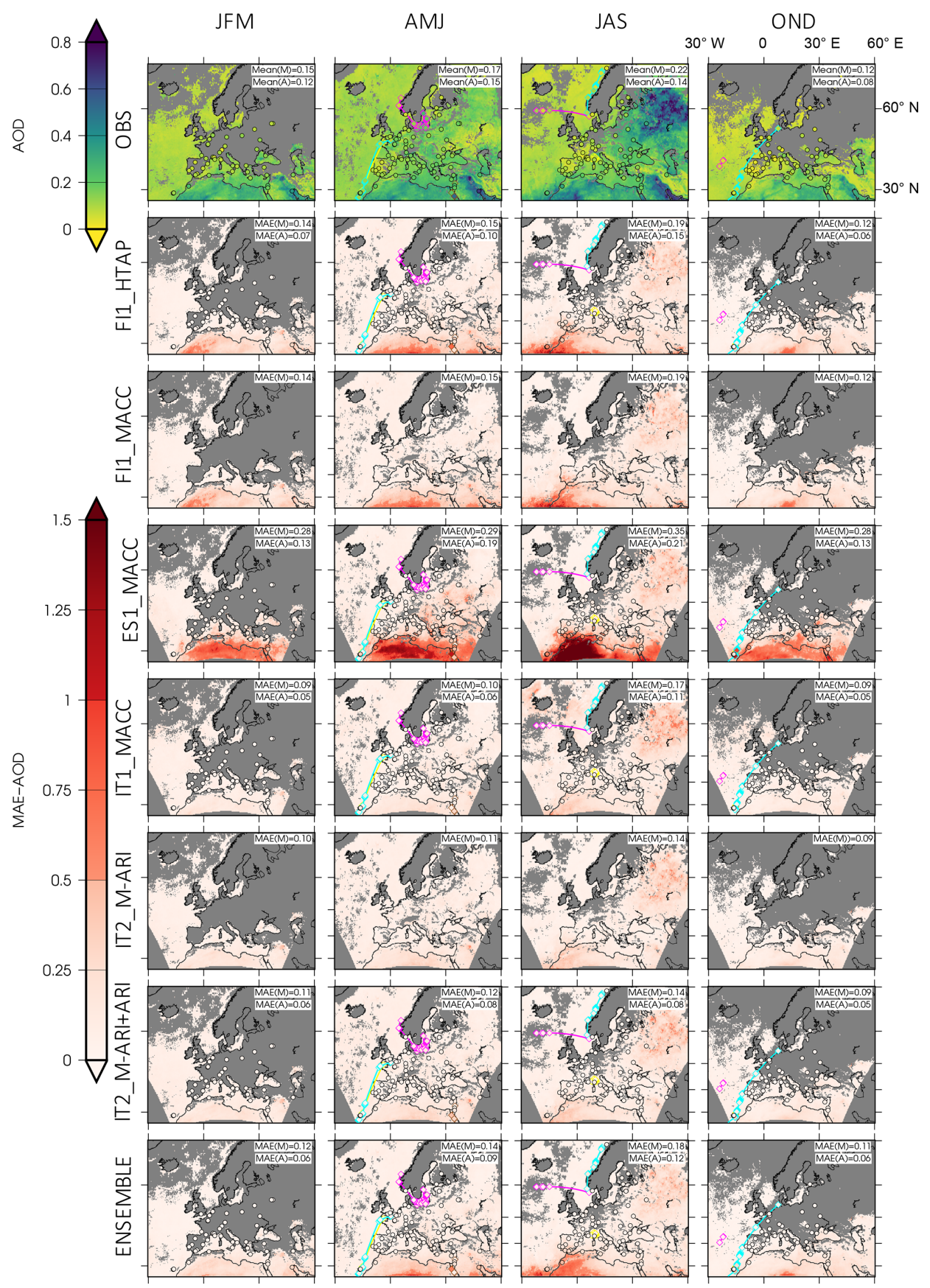

Figure 3. The same as Fig. 2 for the MAE results.

sition in SILAM. This could explain that, although the size distribution is crudely represented, AOD is also very sensitive to this representation.

These values were overestimated over the southern part of the domain (northern part of the Saharan desert), with values around 0.1 . These values were spatially consistent with the higher MAE values (Fig. 3). On the other hand, a slight underestimation was found over the ocean areas probably caused by an underestimation of sea salt from boundary con- ditions. It should be noticed that no clear differences were found among simulations using HTAP and MACC emissions. All the other simulations (ES1_MACC, IT1_MACC, IT2_M-ARI and IT2_M-ARI+ACI) used the WRF meteorological model. When a different chemistry model was used, minor differences in the error were found between those simulations using the CAMx chemistry model (IT1_MACC) and WRF-Chem (IT2). These differences were of a similar order of magnitude to the differences between the IT2 sim- 


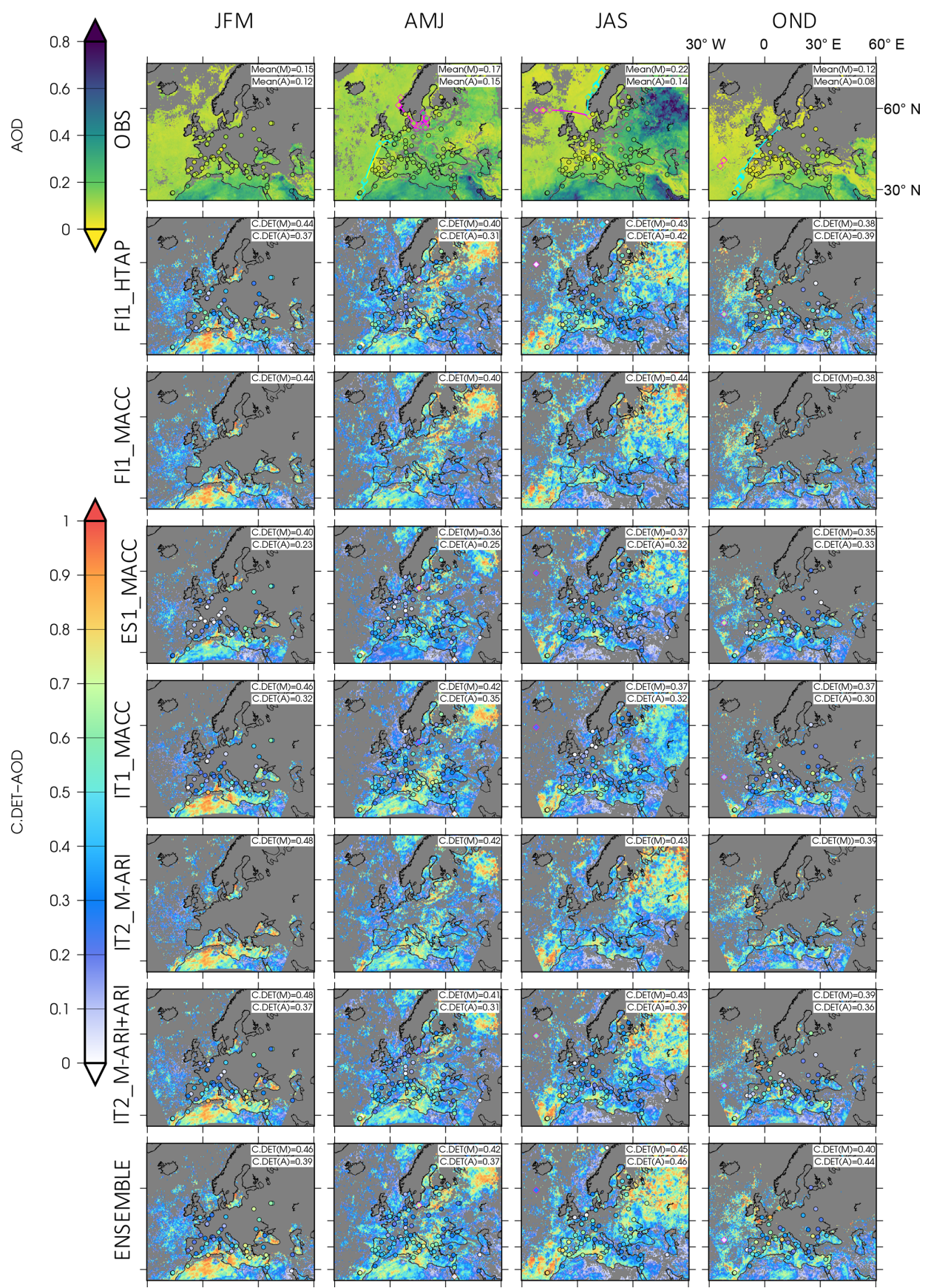

Figure 4. The same as Fig. 2 for the determination coefficient.

ulations including ARIs and ACIs. However, ES1_MACC (using WRF-Chem as the IT2 simulations) presented remarkable differences, by presenting a strong overestimation of AOD over the southern areas of the domain. This marked overestimation occurs because the dust scheme used in ES1_MACC lacked the gravitational settling. Although the IT2 simulations used the same dust scheme and model version, the dust flux was tuned in IT2 to estimate accurate dust concentrations. Hence, ES1_MACC showed the high- est MBE and MAE values throughout the year when compared to both MODIS and AERONET (see labels in Figs. 2 and 3). IT1_MACC presented a general weak overestimation of AOD over the whole domain. IT2 simulations depicted a different behavior. These simulations presented a general weak underestimation except over the southern part of the domain (areas affected by the Saharan dust outbreaks), where AOD was overestimated with low values. The IT1_MACC 
and the IT2 simulations presented the lowest absolute error values (see labels in Figs. 2 and 3).

ENSEMBLE notably overestimated the AOD values over the southern part of the domain, with very high AOD values over the northern part of the Saharan desert. That is consistent with the high MAE values obtained. It should be highlighted that a noticeable underestimation was observed in the simulations over the southeastern part of the domain (represented as a blue spot), centered over Iraq. The ES1_MACC simulation did not show this underestimation because of its high AOD values but presented lower overestimation values (close to 0) over this area than over its surroundings. This small spot was also found for MAE (Fig. 3). This can be explained by the fact that the emission inventories used herein only covered Europe (see the Fig. S5 in the Supplement); thus, the emissions over that area were not considered. Moreover, all the simulations throughout the seasons overestimated the AOD over the southern part of the domain. This was related mainly to the high dust concentrations for the boundary conditions; Solazzo et al. (2017) found that the error in primary species as dust was strongly affected by the emissions and boundary conditions in the AQMEII Phase 3 simulations.

In JFM (first column in Figs. 2 and 3), all the simulations presented a weak underestimation over the Atlantic Ocean, except for IT1_MACC, which presented a weak overestimation in the northern part of the target domain (MBE MODIS mean of 0.01). The abovementioned blue spot was clearly defined over a small southeasterly area and was stronger during this season, even for the ES1_MACC simulation with negative MBE values. For the IT1_MACC, IT2_M-ARI and IT2_M-ARI+ACI simulations, the highest MAE values were consistent over the latter area. FI1 simulations presented an overestimation of AOD over north Africa. This area was larger and with a stronger overestimation for ES1_MACC (MBE MODIS mean of 0.23 and AERONET mean of 0.07 ) for the same reason explained above. ENSEMBLE presented an intermediate behavior, with milder MBE and MAE values (0.02 and 0.12, respectively, for MODIS; 0 and 0.06 for AERONET): an overestimation of the AOD values over north Africa, a very weak underestimation over the Atlantic Ocean and the blue spot centered over Iraq and Syria.

In AMJ (second column in Figs. 2 and 3), the underestimation of AOD was similar to that in winter but with steeper values. All the simulations presented an overestimation (with different degrees) over the southern part of the domain, the Balkan Peninsula and southern Russia. This overestimation was larger and stronger for the ES1_MACC simulation (MBE MODIS mean of 0.21 and AERONET mean of 0.13) and once again presented higher MAE values (0.29, MODIS; 0.19, AERONET). All the simulations, except IT1_MACC, presented a weak underestimation over the Atlantic Ocean. The IT simulations gave lower errors than the rest. As in winter, a small southeasterly area (the blue spot) appeared but was consistent with the maximum MAE values for the IT simulations.

The underestimation of AOD due to the wildfire emissions over Russia and the surrounding areas was one of the most important issues in JAS (third column in Figs. 2 and 3). This underestimation was larger and stronger for the IT2 simulations, and was smaller and weaker for the FI1 simulations. Moreover, the aforementioned small area in the southeastern part of the domain presented higher underestimation values over a larger area than during the other seasons and reached as far as the Persian Gulf. Conversely, the FI1 simulations presented higher values and the IT2 simulations gave lower values. While the overestimation was stronger and affected a larger area than during any other season, this time, the higher overestimation values were found over the northwestern areas of Africa and the Iberian Peninsula. As for the seasons, the ES1_MACC simulation showed the strongest and largest overestimation. During this season, with higher AOD values, all the simulations presented the highest error values.

ENSEMBLE is conditioned by the most remarkable behavior of MBE and MAE in the individual simulations. For example, if a simulation presents a strong underestimation (or overestimation) in a certain area, that is going to seriously impact the ENSEMBLE evaluation results. This is evident over those areas where other individual simulations presented a characteristic skill (mainly the southwestern part of the domain or Russia and the surrounding areas).

In this latter case (Russia area) two possible hypotheses, associated with an inaccurate representation of fire emissions, could explain this underestimation. As established in Palacios-Peña et al. (2018), this underestimation of AOD may be due to a misinterpretation of aerosol vertical profile. In this sense, Soares et al. (2015) found an understated injection height of the total biomass burning emissions. A different hypothesis ascribes this underestimation purely to underestimated emissions. Toll et al. (2015b) found that while the daytime plumes from large fires were indeed lifted higher, the nighttime emissions and emissions from small fires were injected closer to the ground, making the average smoke transport distance even smaller than for the fixed emission height. Also, Soares et al. (2015) points out, after Wooster et al. (2005), that MODIS is not sensitive enough to register the fire radiative power of small or smoldering fires, and thus a large fraction of those is missed in the emission data, including also strongly emitting peat fires. The 2010 Russian fires included some huge fires, but also numerous small ones over large areas, and a large fraction of those was probably missed by MODIS.

OND was the season with the lowest error values (close to zero in most of the domain). All the simulations showed overestimations close to the southern boundary and underestimations over Tunisia and Algeria. Both the overestimation and underestimation were lower for the IT simulations than for FI1. ES1_MACC was the only simulation with a different behavior during this season with a high AOD over- 
estimation over almost all the domain (0.25, MODIS; 0.10, AERONET).

The coefficient of determination $\left(r^{2}\right)$ (Fig. 4) was higher than 0.5 over most of the domain when comparing the simulation results against MODIS. In JFM, the highest $r^{2}$ values (around 1.0) were found over the northeastern part of the African continent. In AMJ, these high values were found over central and eastern parts of Europe and north Africa. In JAS, the highest $r^{2}$ values correspond to Russia and its surrounding areas, and a part of the Atlantic Ocean in the southwestern part of the domain. Finally, in OND, $r^{2}$ was lower than for the other seasons, especially over the Mediterranean Sea and the Atlantic Ocean.

\subsection{Model evaluation of the AE representation}

AE indicates the relationship between the size of the particles suspended in the atmosphere and the wavelength of the incident light, and although there is not a direct correspondence between aerosol size and $\mathrm{AE}$, this exponent provides an idea of the size of particles. Low AE values are related to coarse particles, such as desert dust or sea salt, and high values are associated with fine particles, such as anthropogenic source particles or biomass burning. The AE values are usually between 0 (or even slightly negative in coarse-mode aerosol episodes) and 4 (Boucher, 2015). AE data from simulations are less available than for AOD because some models did not provide AOD at different wavelengths, and therefore it was not possible to estimate AE following the methodology established above.

Seasonal means of AE between 550 and $860 \mathrm{~nm}$ satellite values (only estimated over the sea) and between 440 and $860 \mathrm{~nm}$ from AERONET stations and MAN data, are shown in the first row in the AE figures (Figs. 5, 6 and 7). Generally, through the different seasons, low AE values were found offshore, where sea salt particles (coarse) predominated. Over the Mediterranean coast near the Saharan desert, low values were found due to the frequent desert dust outbreaks. High values were observed over coastal areas and inland in central Europe due to fine anthropogenic emissions (e.g., onroad traffic). Moreover, these values became lower from inland to offshore. In JFM, (first column in the first row in the AE figures) and OND (fourth column), the lowest values were found over the Atlantic Ocean and the Mediterranean Sea. Similarly, high AE values (around 1.5) were found over coastal areas and inland in central Europe. In OND, a small area over the north of the Caspian Sea with values of 2.5 was found. In AMJ, as represented in the second column in the first row in the AE figures, the $\mathrm{AE}$ values showed a narrow range between 1.0 and 1.5 over most of the domain. Some exceptions were found for values close to 0.5 near the African continent and values close to 2.0 in northern Europe. It is noteworthy that low AE values (close to 0.5) were uniformly distributed in AMJ over the southern part of the domain, while in JAS (third column in the first row in the AE figures), the lowest AE values (lower than 0.5) were found mainly over the southern Atlantic Ocean. Values between 2.0 and 2.5 were estimated over northeastern coasts and over central and northern Europe and the north of the Black Sea and Caspian Sea. As for AOD, AERONET stations and MAN data showed very similar values to MODIS. As AERONET stations are located over the continent, the temporal and spatial mean of the results provides higher values due to a higher influence of anthropogenic emissions.

On a broad view through the different seasons, FI1_HTAP (driven by the ECMWF meteorological model and the SILAM chemistry model) underestimated the AE over most of the domain. This underestimation was higher over areas near European coasts and inland, where the observations showed values around 1.5. The general underestimation was lower over the southwestern part of the domain, where AE observations were close to 0.5 . This simulation also presented the highest MAE values. This model estimated largersized particles than those retrieved by observations. As previously mentioned, SILAM crudely represents the particles' size distribution, which impacted the AE representation because it may have centered the size distribution on particles with a larger diameter. Despite the results obtained for AOD representation evaluation (due to the lack of dust gravitational settling), ES1_MACC presented low error values (MBE and MAE) through the different seasons for AE. This could be explained by the high dust concentration over southern areas, resulting in low AE values and thus compensating the tendency for producing high $\mathrm{PM}_{2.5} / \mathrm{PM}_{10}$ ratios (Solazzo et al., 2012, 2014; Balzarini, 2013). A very low overestimation was found over areas close to Africa, and a more noticeable underestimation was found over areas near the European coast and inland. The IT1_MACC simulation generally overestimated the AE values over the Atlantic Ocean and the Mediterranean Sea (areas with AE close to 0.5). Over the areas near the coast of central and northern Europe, where the observations gave values around 1.5 , this simulation presented a smaller underestimation than the other simulations. The IT2_M-ARI+ACI simulation showed an overestimation over the Atlantic and Mediterranean coast near north Africa, and a weak underestimation over the coasts of the North Sea and Baltic Sea, and inland over the available AERONET stations. IT_MACC (WRF coupled to CAMx) and both WRFChem simulations (ES1_MACC and IT2_M-ARI+ACI) underestimated high $\mathrm{AE}$ values and overestimated low $\mathrm{AE}$ values, and thus they underpredicted the variability of this variable, consistently with Palacios-Peña et al. (2017, 2018). On the other hand, Solazzo et al. $(2012,2014)$ and Balzarini (2013) found a severe underestimation for $\mathrm{PM}_{10}$ concentrations over Europe for the WRF-CAMx and WRF-Chem models, which could explain the overestimation of low AE values. Moreover, they also found an underestimation of $\mathrm{PM}_{2.5}$ concentrations which could also explain the underestimation of high AE values, since simulated particles underestimate the variability of the size distribution. Finally, 

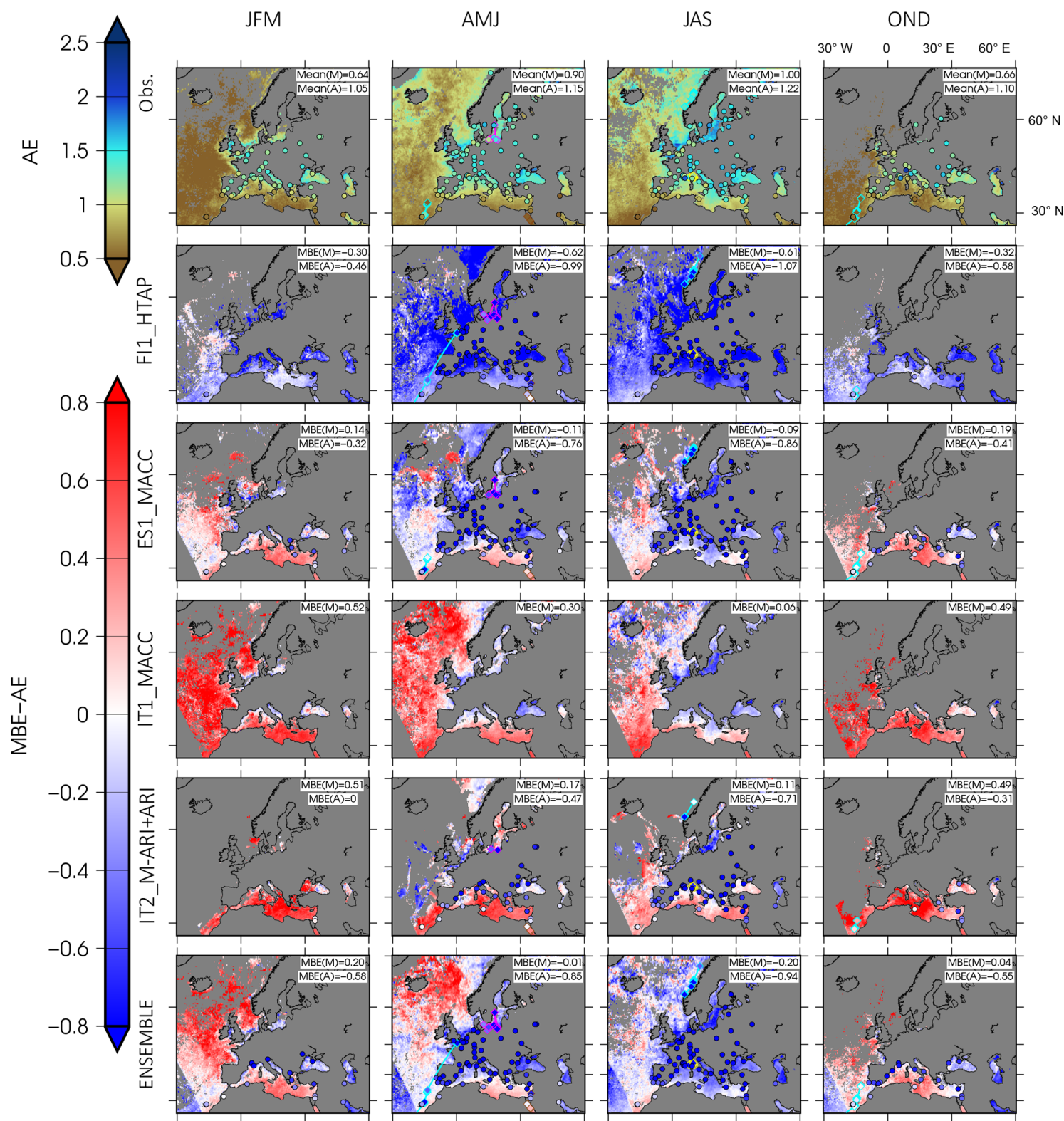

Figure 5. MBE results of AE between 550 and $860 \mathrm{~nm}$ from satellite and AE between 440 and $870 \mathrm{~nm}$ from AERONET (points) and MAN (colored diamond) values versus simulations at the same wavelengths. Columns from left to right: temporal mean of winter (JFM), spring (AMJ), summer (JAS) and autumn (OND). First row: satellite values; from the second row to the bottom: the MBE values of FI1_HTAP, ES1_MACC, IT1_MACC, IT2_M-ARI+ACI and ENSEMBLE. Bonded lines between diamonds represent the boat track during AMJ: Oceania (magenta), Polarstern (cyan) and Zim Iberia (chocolate); JAS: Alliance (yellow) and Oceania (cyan); and OND: Polarstern (cyan). Values in every plot indicate the spatial and temporal average of MBE for MODIS (MBE(M)) and AERONET (MBE(A)).

ENSEMBLE presented a noticeable underestimation of the AE values over the European coast (including the Mediterranean Sea) and inland, probably due to the strong underestimation provided by the FI1_HTAP simulation strongly conditioning the results of ENSEMBLE. Very low overestimation values were obtained over the Atlantic Ocean and near African coasts in the southern Mediterranean Sea. Moreover, ENSEMBLE and the other simulations presented a strong underestimation over the two small areas with AE values around 2.5. It is noteworthy that the evaluation results for the Polarstern ship of MAN during OND showed negligible bias values.

JFM results are represented in the first column in Figs. 5 and 6. The FI1_HTAP simulation generally showed an underestimation of the $\mathrm{AE}$ values ( -0.30 MODIS and -0.46 AERONET), which was stronger over areas near the European coast and the available AERONET stations. ES1_MACC presented the lowest error values (0.14 MODIS 


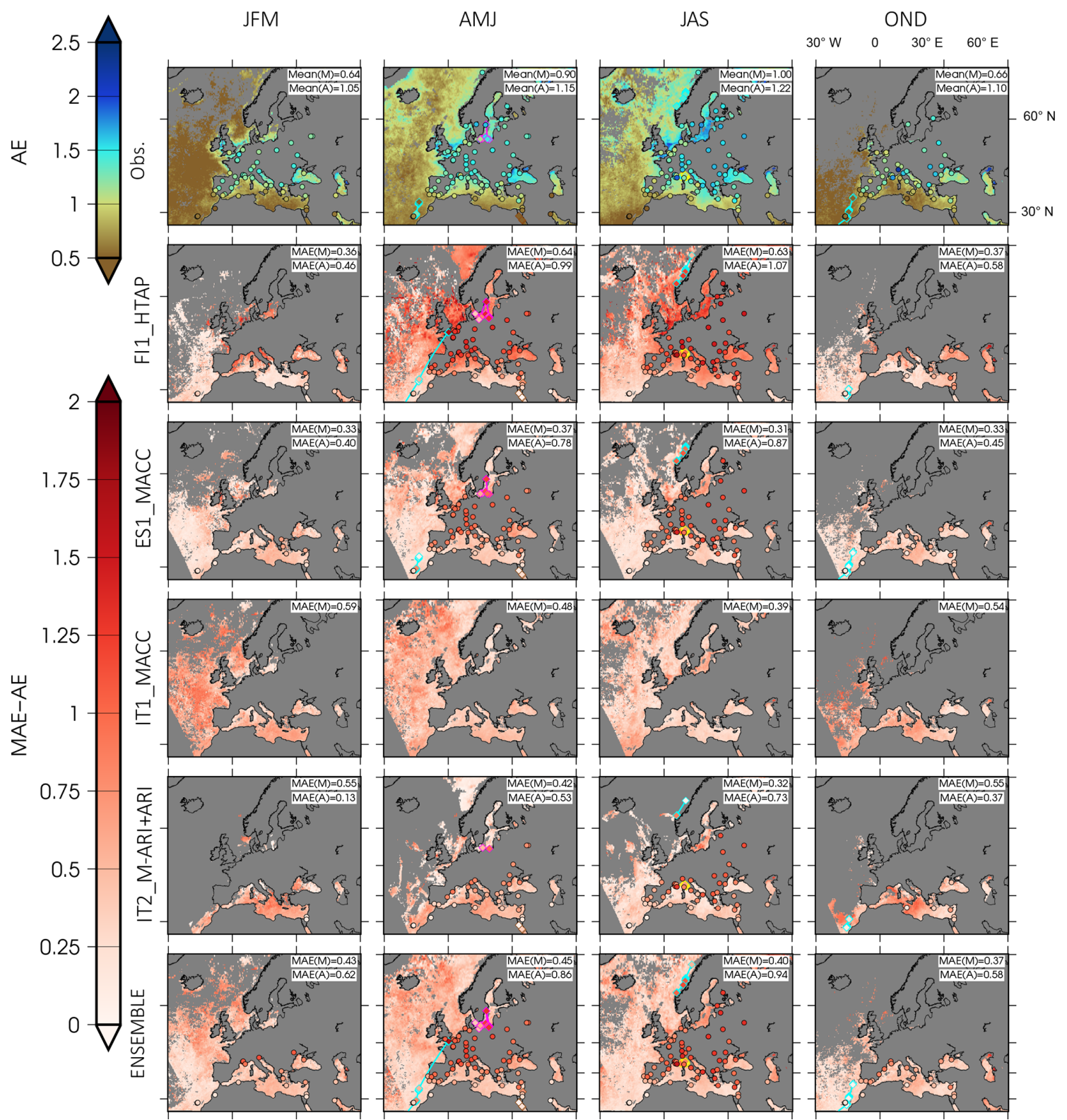

Figure 6. The same as Fig. 5 for the MAE results.

and -0.32 AERONET for MBE; 0.33 MODIS and 0.40 AERONET for MAE). This simulation slightly underestimated the AE values over the Atlantic Ocean and the Mediterranean Sea, and presented an underestimation over small areas close to the European coast and over AERONET stations. Both the IT1_MACC and IT2_M-ARI+ACI simulations gave a general overestimation over most of the domain. IT1_MACC showed a very slight underestimation of the AE close to the European coast, but this simulation had the highest error values due to the strong overestimation. However, IT2_M-ARI+ACI displayed a really low bias (temporal and spatial AERONET MBE of 0) when compared with the available AERONET stations. ENSEMBLE depicted a high over- estimation over the North Atlantic and the Mediterranean Sea, and a small underestimation close to the European coast and inland.

The second column of Figs. 5 and 6 shows the results obtained in AMJ. For this season, FI1_HTAP underestimated the AE values over most of the domain and presented the highest error values (MBE of -0.62 and MAE of 0.64 against MODIS). This underestimation was larger when this simulation is compared with AERONET stations (MBE of -0.99 and MAE of 0.99). ES1_MACC displayed an intermediate behavior when compared to the other simulations, with a weak overestimation over the north African coast and a more noticeable underestimation over the northern part of the 

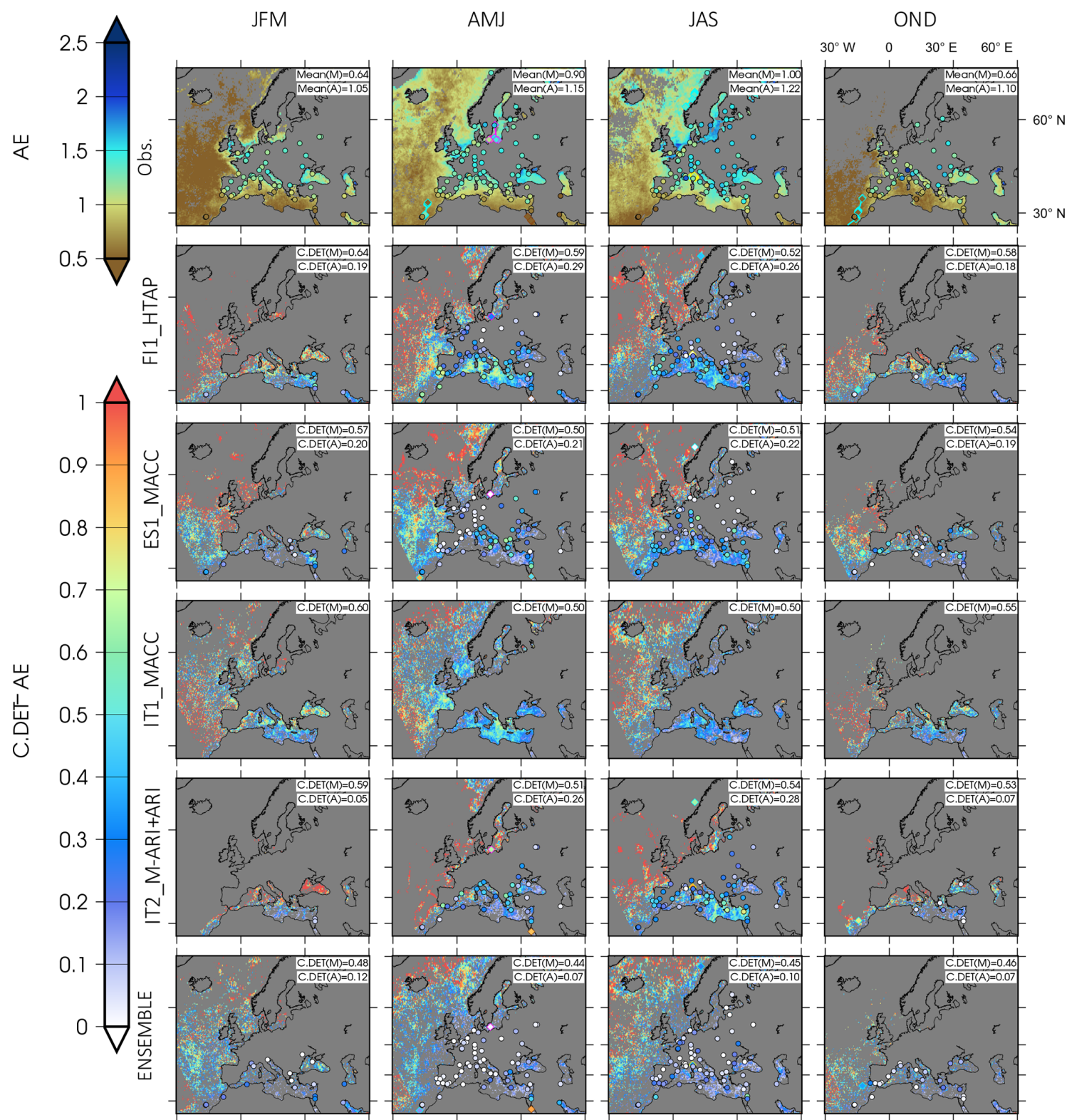

Figure 7. The same as Fig. 5 for the determination coefficient.

domain. Notwithstanding, ES1_MACC presented the lowest absolute error when compared with MODIS. For AERONET, the lowest values were found for IT2_M-ARI+ACI, but this is probably because this simulation was not evaluated for northerly stations. IT1_MACC overestimated the AE values over the Atlantic Ocean and the southern part of the domain, and underestimated $\mathrm{AE}$ in areas over the European coast. IT2_M-ARI+ACI overestimated the AE values over the Moroccan Atlantic coast and the southern Mediterranean Sea, but small areas of underestimation were found over the Azores islands and the northern coast of France. Moreover, values over the European AERONET stations were underestimated. Finally, ENSEMBLE produced a general under- estimation over most of the domain, for both MODIS and AERONET. The overestimation was produced mainly over an area that lies north of the British Isles and the southeastern part of the domain, where satellite values came close to 0.5 .

All the simulations run for JAS (third column in Figs. 5 and 6) displayed similar skills as in AMJ. Generally speaking, FI1_HTAP underestimated the AE values and presented the highest errors. During this season, ES1_MACC showed a larger area of underestimation and a smaller area of overestimation but with similar error values as in spring. The overestimation of IT1_MACC was weaker, but the underestimation was stronger and over a larger area over the North Sea 
and Baltic Sea. IT2_M-ARI+ACI also produced an overestimation over most of the domain, but it was weaker than for AMJ. Notwithstanding, this simulation presented a small area of underestimation over the Baltic sea. However, ENSEMBLE displayed a general underestimation that lowered from inland to offshore.

In OND (fourth column in Figs. 5 and 6), the behavior of simulations was similar to that shown in winter. FI1_HTAP produced a general but weaker underestimation than in AMJ and JAS. During this season, ES1_MACC produced a general overestimation over the Atlantic Ocean and the Mediterranean Sea and an underestimation over the inland AERONET stations, but once again it gave the lower error values. IT1_MACC and IT2_M-ARI+ACI overestimated AE values over most of the domain with similar MBE and MAE values but underestimated $\mathrm{AE}$ values in eastern AERONET stations. Finally, ENSEMBLE depicted a weak overestimation over the Atlantic Ocean and the Mediterranean Sea, and a slight underestimation over the Black, Caspian and Red seas. The values of all AERONET stations were also underestimated.

Figure 7 shows the results of the determination coefficient $\left(r^{2}\right)$. FI1_HTAP and IT1_MACC showed relatively high values (around 0.5) over the Mediterranean Sea, but over this area, all the other simulations presented values above 0.25 . However, $r^{2}$ values were low when simulations were compared with AERONET stations and MAN data. It was very difficult to find a clear pattern for the coefficient of determination. During each season, FI1_HTAP showed the highest determination values and ENSEMBLE the lowest $r^{2}$.

\subsection{Variability}

A good approach to evaluate the spatial and temporal variability of a variable is the PDF. This represents the density of counts for each value of the variable. In order to study how the AQMEII Phase 3 simulations represented the variability of AOD and AE, the PDFs of both variables for each studied season are shown in Fig. 8. In that figure, the first left column corresponds to the PDF of AOD at $550 \mathrm{~nm}$, second column to AOD at $675 \mathrm{~nm}$, third column to AE between 550 and $860 \mathrm{~nm}$ and fourth to AE between 440 and $870 \mathrm{~nm}$. The first row corresponds to winter (JFM), second to spring (AMJ), third to summer (JAS) and bottom row to autumn (OND). Observed values (MODIS in the first and third columns and AERONET in second and fourth) was represented by a black line, ENSEMBLE by a red line, FI1 simulations by green dashed lines, ES1 by a yellow dashed line, IT1 by a cyan dashed line, IT2_M-ARI by a blue dashed line and finally IT2_MARI+ACI by a blue dotted line. Due to the small number of MAN occurrences, these data are not shown in this section. PDFs for MODIS and AERONET data were evaluated separately because they were not represented by the same variable and over the same space and time. However, they represented a similar behavior regarding the comparison of the variability of the simulations against observations.

The PDFs of AOD for the data corresponding to winter (JFM), spring (AMJ) and autumn (OND) presented a similar behavior, both for MODIS and AERONET. The observed values showed a high probability for low values (between 0 and 0.5$)$. The PDF of IT1_MACC for these seasons was the most similar one to both observation datasets. For these three seasons, this was the simulation with a lower absolute error when the temporal standard deviation from the simulations was evaluated against observations, as we can see in the Supplement. During autumn, AERONET data and their respective PDFs from simulations are narrower than those from MODIS, so the AOD values, both observed and modeled, were lower over AERONET stations. In JFM and OND, FI1 and IT2 displayed analogous PDFs with the highest probability for the lower AOD simulated values than those observed. However, during AMJ, these four simulations gave almost equal PDFs. ES1_MACC showed a remarkable skill for the representation of AOD in all seasons when compared with AERONET. The PDFs for this simulation estimated higher probabilities for high AOD values than the other simulations and the observed values. This fact was again due to the abovementioned lack of gravitational settling in the dust scheme used. For this reason, the probability of low AOD values was lower than for the rest. This behavior was not observed when this simulation was compared against AERONET values, when the ES1_MACC PDF was similar to the rest. In JFM, AMJ and OND, ENSEMBLE displayed a high probability for lower AOD simulated values than those observed; but with ENSEMBLE, the probability for the higher AOD values was higher than for observations.

The PDFs of the AOD representation were different in JAS. For this season, both IT2 simulations depicted the closest behavior to the observed PDF values. As seen in the Supplement, these simulations displayed the lowest MAE compared with the observed standard deviation. All the simulations and ENSEMBLE in this season presented a higher probability for the high AOD values than for observations.

The third and fourth columns of Fig. 8 represent the PDFs for the MODIS and AERONET AE values, respectively. As for AOD, JFM and OND presented similar PDFs to MODIS observed values. The observed MODIS AE values showed a high probability for the low AE values, around 0.5 , and a low probability for the high AE values. For AERONET, winter and autumn PDFs displayed high probability values for low $\mathrm{AE}$ values, but these showed higher probability for higher values than those observed in MODIS. For AMJ and JAS, the PDFs for the MODIS observed values were tray-shaped, with a high probability for $\mathrm{AE}$ values between 0.5 and 1.5. As well as in OND, these PDFs displayed their highest probabilities for AE values around 1.5. AERONET stations in AMJ and JAS showed a probability which increased from AE values of 0 to 2 , where the probability decreased. 

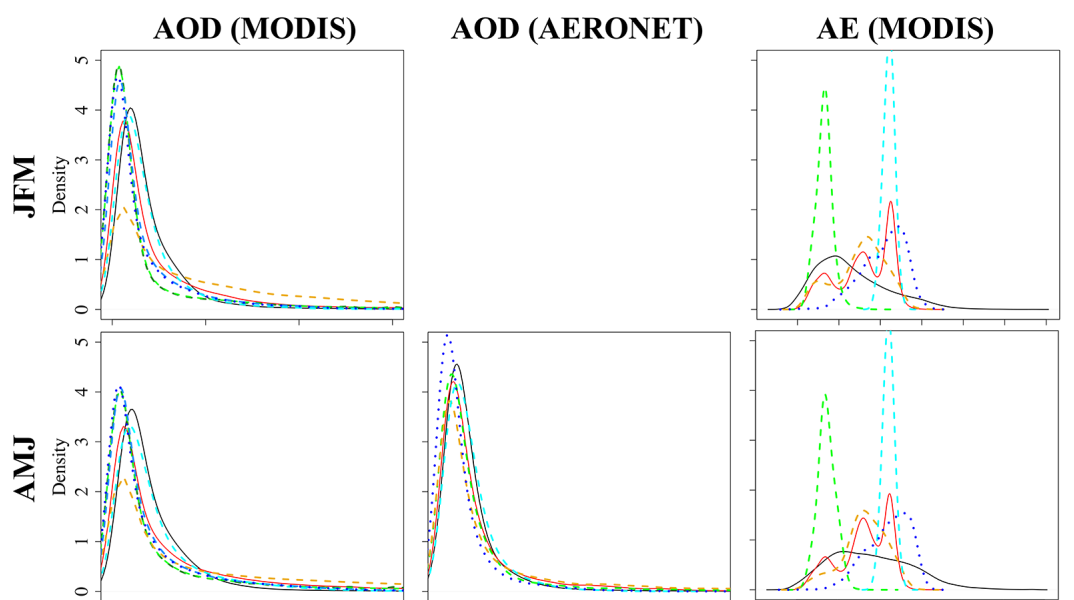

AE (AERONET)
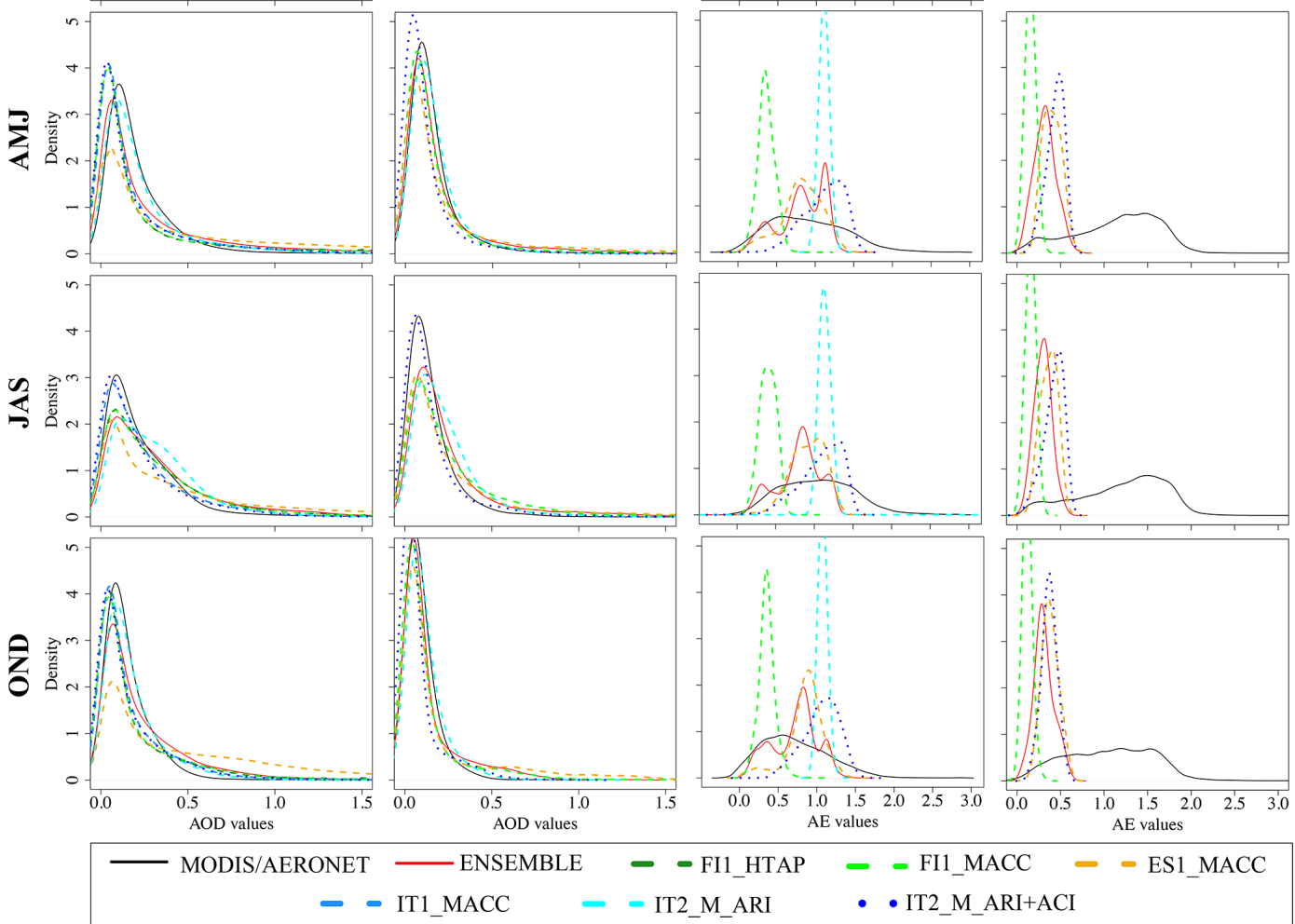

Figure 8. PDFs for AOD (first, MODIS and second, AERONET columns) and AE (third, MODIS and fourth right, AERONET) values. From the top to the bottom: JFM, AMJ, JAS, OND.

The FI1_HTAP simulation depicted a high probability for very low AE values, between 0 and 0.6 for MODIS, and 0 and 0.4 for AERONET. IT1_MACC gave similar PDFs for all the seasons, and a high probability was found for AE between 1 and 1.5. FI1_HTAP and IT1_MACC were the simulations with the narrowest PDFs, pointing out a strong underestimation of the observed variability of the $\mathrm{AE}$ (as was also indicated in the evaluation of the temporal standard deviation shown in the Supplement). The PDFs for ES1_MACC, IT2_M-ARI+ACI and ENSEMBLE were wider than for the other simulations. ES1_MACC and IT2_M-ACI+ACI showed a higher probability for AE values from 0 to 2 for MODIS and 0 to 0.7 for AERONET. However, IT2_M-ARI+ACI showed a high probability for slightly higher AE values than in the case of ES1_MACC. The behavior of ENSEMBLE was similar in all seasons and showed a medium behavior when compared to the rest of the simulations. ENSEMBLE showed a high probability that ranged from 0 to 1.5 for MODIS and 0 to around 0.7 for AERONET. Notwithstanding, all the simulated PDFs were narrower than the PDF for the observed values; thus, all the simulations underestimated the representation of the AE. This is observed in the Supplement, where the estimation of the MBE of the standard deviation gave negative results for all the seasons and simulations. The low variability of the simulations inland is noticeable (over AERONET stations). Meanwhile, during all the seasons, AERONET displayed a PDF between 0 and 2 AE values; the evaluated simulations displayed PDFs between 0 and 0.6 for $\mathrm{AE}$, indicating that all the simulations displayed really low $\mathrm{AE}$ values inland.

\section{Summary and conclusions}

Although AQMEII Phase 3 focuses on evaluating and intercomparing regional and linked global/regional modeling systems, an evaluation of the simulations against observa- 
tions was necessary in order to have an educated guess on the skill of the simulations when representing aerosol optical properties. Solazzo et al. (2017) analyzed the performance of models for different meteorological variables and chemical species. In order to perform a more detailed analysis of the performance of the models, this work focused on evaluating the representation of aerosol optical properties by using AQMEII Phase 3 simulations and remote-sensing observations. The evaluation of these variables is important because they strongly influence ARIs and ACIs and thus influence the atmospheric aerosol effects on the climate system.

As the Mediterranean region is frequently affected by Saharan desert dust outbreaks, and an area over Russia and the surrounding during summer 2010 was affected by wildfires, those areas presented the highest AOD for the year 2010. These AOD values were similar in both databases used: MODIS and AERONET (and, when applicable, MAN). As the AOD evaluated from each database was available at a different wavelength, some aspects in the evaluation differed. This was because all the simulations provided AOD at $550 \mathrm{~nm}$ and they could be evaluated against MODIS data, but not all them had AOD at $675 \mathrm{~nm}$ available (as for FI1_MACC and IT2_M-ARI, which only provided AOD at $550 \mathrm{~nm}$ ). Thus, there were no means of estimating AOD at $675 \mathrm{~nm}$ for comparison to AERONET data. This fact resulted in a lower number of simulations but with more trustable values. As previously mentioned, here ENSEMBLE was merely calculated as the mean of all the available simulations; thus, ENSEMBLE results show a mean behavior of the available simulations and in any case, this ENSEMBLE has been built with at least four simulations for the sake of representativeness.

All the simulations presented similar AOD spatial patterns and provided a good representation of the low and mean AOD values. Slight AOD underestimations for all the simulations were found over the Atlantic Ocean, and this fact could be attributed to an underestimation of the sea salt concentrations. Albeit different models in this work used different schemes to estimate sea salt emissions, this underestimation could be attributed to an underestimation in the boundary conditions, which are the same for all the simulations. On the other hand, a major underestimation occurred during the wildfire episode over Russia in summer 2010. This underestimation is common for all the simulations regardless of the emission inventory, the model or the configuration used. Differences when different emission inventories were used could be expected but, as mentioned above, all AQMEII Phase 3 simulations used the same fire emissions nevertheless. Thus, this AOD underestimation should be bonded with an underestimation of the fire emissions. Toll et al. (2015b) found that while the daytime plumes from large fires were indeed lifted higher, the nighttime emissions and emissions from small fires were injected closer to the ground, making the average smoke transport distance even smaller than for the fixed emission height. Also, Wooster et al. (2005) pointed out that MODIS is not sensitive enough to register the fire radiative power of small or smoldering fires, and thus a large fraction of those is missed in the emission data, including also strongly emitting peat fires. The 2010 Russian fires included some huge fires but also numerous small ones over large areas, and a large fraction of those was probably missed by MODIS. A different hypothesis, established in PalaciosPeña et al. (2018), ascribes this underestimation to a misrepresentation of the aerosol vertical profile modeled and may therefore be caused by the AOD representation given the understated injection height of the total biomass burning emissions found by Soares et al. (2015).

Moreover, a large underestimation was produced for all the simulations, irrespectively of the used meteorological and chemical model or emission inventory, over a small area in the southeastern part of the domain (the aforementioned "blue spot"). This can be explained by the fact that both emission inventories used herein only covered European areas (see the emission map in the Supplement); thus, the emissions over that area were not included in the simulations. In addition, the AOD over the southern part of the domain was overestimated and this is related mainly to the high dust concentrations in the boundary conditions. In line with this, Solazzo et al. (2017) found that the error in primary species as dust was strongly affected by the emissions and boundary conditions in the AQMEII Phase 3 simulations.

Overall, FI1 simulations, which used the ECMWF files as SILAM model input, presented negative or negligible MBE values. It means that these simulations estimated higher AOD values than the rest of the simulations. This fact is explained because SILAM is known to have slower dry particle deposition than other models. This could explain that, although the band quite crudely represented size distribution, AOD is also very sensitive to the particle size representation. Moreover, no differences between FI1 simulations (different emission inventories) were found, pointing out a low impact of the use of different emission inventories on the AOD representation. This fact can be observed when FI1 simulations were compared with the rest of the simulations: differences are higher due when using different meteorological or chemistry models than when implementing different emission inventories. IT1 (WRF meteorological conditions for CAMx) depicted slight positive MBE values. This could be due to the aerosol size range $(40 \mathrm{~nm}$ to $10 \mu \mathrm{m})$ used by the AODEM tool. This tool calculated the optical properties from the aerosol mass concentration predicted by CAMx. As found by Permadi et al. (2018), when these authors applied the AODEM tool to WRF-CHIMERE outputs, an AOD underestimation due to the lack of coarse particles (above $10 \mu \mathrm{m}$ ) was expected. However, the use of mass concentration of aerosols with size range up to $10 \mu \mathrm{m}$ could produce a high impact on aerosol optical properties, because absorbing particles as black carbon predominate within this size range. Hence, this could produce an overestimation in the AOD estimation, as for IT1. ES1 (WRF-Chem) presented a high AOD overestimation due 
to the dust outbreaks. This marked overestimation took place because of the dust scheme lacked the gravitational settling. Although IT2 simulations used the same dust scheme and model version, the dust flux was modified for these simulations to estimate accurate dust concentrations, and hence these simulations presented lower AOD values.

The added value when the IT2 simulations were analyzed was the inclusion of ARIs in one of them (IT2_M-ARI) and the inclusion of ACIs and aqueous chemistry in convective clouds in the other one (IT2_M-ARI+ACI). However, no important differences were observed for the AOD representation among them. Thus, the differences in the use of a different meteorological and chemistry model were stronger than the implementation of aerosol radiative feedbacks. However, IT2_M-ARI+ACI showed more negative MBE values than IT2_M-ARI, indicating that the simulations which include a complex treatment of clouds displayed lower AOD values. Romakkaniemi et al. (2012) found a relationship between a reduction in the AOD and the CCN. The inclusion of the ACIs produces a reduction in the $\mathrm{CCN}$ by the condensation kinetics of water during cloud droplet formation. This results in a reduction of the cloud droplet number, the cloud liquid water and, finally, an increase in downward solar radiation, as also found by Forkel et al. (2015) when ACIs were taken into account in the AQMEII Phase 2 simulations.

It is important to highlight that for all the simulations and seasons, the highest determination coefficient $\left(r^{2}\right)$ values were obtained over the areas with mean AOD values (observed values between 0.5 and 1.0), which were approximately the areas with the lowest error values. Thus, all simulations were skillful for representing the seasonal mean AOD values. The use of an ensemble (defined as the mean of all the participant simulations) improved this statistical figure.

High AE values (indicating a strong presence of fine particles) were found near central European coasts and inland, probably influenced by anthropogenic emissions. Low $\mathrm{AE}$ values (coarse particles) were observed over the southern part of the domain, close to the Saharan desert and over the Atlantic Ocean. It was also noteworthy that the AE values over the Atlantic Ocean were generally much higher in spring and summer than in autumn and winter. This means that the aerosol particles over ocean areas and near the coast in warm months were apparently finer than in colder months. This might be related to two different hypotheses: (a) weaker winds in warm months or (b) hygroscopic growth, which could be greater in cold months generally because of higher relative humidity $(\mathrm{RH})$.

AE modeling skills were lower than for AOD (larger errors). The simulation run with the SILAM model and using the ECMWF meteorological inputs (FI1_HTAP) largely underestimated $\mathrm{AE}$ over most of the domain (when compared to MODIS and AERONET). Hence, this model estimated larger-sized particles than observations. As previously mentioned, SILAM roughly represents size distribution, which impacted the $\mathrm{AE}$ representation because size distribution centers on particles with a larger diameter. A different hypothesis could be ascribed to the use of different anthropogenic emissions, since FI1_HTAP is the only case when the HTAP emissions were used. The simulations using WRF coupled to the CAMx model (IT1_MACC) and both WRFChem simulations (ES1_MACC and IT2_M-ARI+ACI) underestimated high $\mathrm{AE}$ values and overestimated low $\mathrm{AE}$ values. Thus, they underpredicted the variability of this variable. These results are similar to those established in PalaciosPeña et al. $(2017,2018)$. On the other hand, Solazzo et al. (2012, 2014), Balzarini (2013) and Im et al. (2015) found a severe underestimation of $\mathrm{PM}_{10}$ concentrations over Europe for WRF-CAMx and WRF-Chem models, which could explain the overestimation of low $\mathrm{AE}$ values. These authors also found an underestimation of $\mathrm{PM}_{2.5}$ concentrations which could also explain the underestimation of high AE values since simulated particles underestimate the variability of the size. An interesting fact is found for ES1_MACC: despite the lack of dust gravitational settling, it presented the lowest bias for AE. This could be explained by the high dust concentration over southern areas, resulting in low AE values and thus compensating the tendency for producing high $\mathrm{PM}_{2.5} / \mathrm{PM}_{10}$ ratios.

A clear difference was found in the use of a different meteorological model when the $\mathrm{AE}$ values were evaluated. FI1_HTAP (ECMWF meteorological inputs) highly underestimated AE values, while the simulations which used WRF as meteorological driver produced an underestimation of high $\mathrm{AE}$ values and an overestimation of low values. This could be related to a misrepresentation of the RH by each meteorological model and the strong influence of RH in the aerosol optical properties due to hygroscopic growth (Yoon and Kim, 2006; Altaratz et al., 2013; Palacios-Peña et al., 2017).

As AODs at different wavelengths were not available for several runs, it was not possible to apply the AE estimation method explained in Sect. 2.3 for all the simulations. Moreover, the spatiotemporal coverage of the entire domain for $\mathrm{AE}$ simulations could be affected by the restrictions established in the same section regarding data quality, reducing the number of available data for AE evaluation. However, those restrictions made $\mathrm{AE}$ values more trustable for model evaluation. ENSEMBLE was used as the mean of the available simulations for the different $\mathrm{AE}$ values at different wavelengths.

No clear spatial pattern was found for the coefficient of determination of AE. One striking fact in this case was that using the mean of all the simulations as an ENSEMBLE simulation did not improve $r^{2}$ with respect to individual simulations. In fact, the worse $r^{2}$ results were found for ENSEMBLE, while the highest $r^{2}$ was presented for FI1_HTAP (despite its high underestimation of the AE values, FI1_HTAP skill in the temporal $\mathrm{AE}$ representation was good).

A good approach to evaluate the spatial and temporal variability of a variable is a PDF. A wide PDF indicates high variability for the studied variable, and a narrow PDF points out a low variability. For AOD representation, all the simula- 
tions presented a similar PDF to the observed values. The behavior of all the simulations was similar in winter, spring and autumn; FI1 and IT2 presented higher probabilities for lower AOD values than those observed; ES1 presented higher probabilities for high AOD values than those observed due to the above-explained misrepresentation of the dust gravitational settling. Finally, IT1 presented the most skillful PDF, except during summer (best skills for IT2_M-ARI+ACI given the higher probability of obtaining AOD values around 0.5 ). Regarding IT2 simulations, although IT2_M-ARI+ACI had higher MBE values when compared with IT2_M-ARI, the former presented better skills in the representation of the variability of $\mathrm{AOD}$. One general conclusion can be extracted from the analysis of the PDF of AE: for this variable, all the simulations in all the studied seasons underestimated spatiotemporal variability.

Summarizing, the errors in all the simulations for AOD were lower than for AE. For AOD, low and mean values were well represented, but high values presented larger errors. High AOD values were overestimated because of an overestimation in the dust boundary conditions. The high AOD values due to biomass burning were underestimated, which should be ascribed to an understated injection height of the total biomass burning emissions or directly to underestimated fire emissions. Other high AOD values were underestimated because the emissions which produced these high values were not considered. The errors in the AOD evidenced the strong influence of emissions and boundary conditions in the estimation of aerosol optical properties. Generally speaking, the skills to represent the variability of AOD were acceptable. For AE, the SILAM simulation underestimated the observed values, and the WRF-CAMx and WRF-Chem simulations were those with the best skills in the representation of this variable. Overall, for all the simulations, the variability of this variable was pervasively underestimated.

There was a high impact in the use of different physical and chemical mechanisms used by each model. Differences were found when ECMWF meteorological inputs were used by the SILAM model (more pronounced for AE), in contrast to the chemistry models which used WRF as a meteorological model. This supports the conclusion that the evaluation of air quality models needs to be supported by the analysis of meteorological fields found by Solazzo et al. (2017). Regarding the aerosol optical properties, there is a really high influence of the RH due to the hygroscopic growth (Yoon and Kim, 2006; Altaratz et al., 2013; Palacios-Peña et al., 2017). Differences between the model system used (combination of meteorology and chemistry) were higher than the differences due to the use of a different anthropogenic emission inventory or the inclusion of aerosol radiative feedback (ARIs and ACIs).

Regarding emission datasets, there is not a high influence when a different anthropogenic emission inventory was used. However, there was a high influence of the emissions of primary particles as biomass burning emissions, whose misrep- resentation produces an impact in aerosol optical properties. When the aerosol radiative feedbacks were taken into account, the inclusion of the ACIs and more complex cloud processes resulted in lower AOD values (higher errors) but a better skill in the representation of the variability of this variable.

Henceforth, further studies are needed to improve the representation of aerosol optical properties, along with other properties such as atmospheric distribution and hygroscopicity or the ability to act as cloud condensation nuclei and ice nuclei. The results presented here for the representation of aerosol properties can help improve the process understanding of ARIs and ACIs. Also, aerosol effects on meteorology and climate could reduce (or, at least, help characterize) the uncertainty in the estimations of changes in the Earth's radiation budget due to aerosols and clouds.

Data availability. The outputs from the simulations can be obtained by emailing rbianconi@enviroware.com. MODIS data are publicly available on the MODIS atmosphere website (https://modis-atmos.gsfc.nasa.gov/MOD04_L2/acquiring.html, NASA Official, 2017)

Supplement. The supplement related to this article is available online at: https://doi.org/10.5194/acp-19-2965-2019-supplement.

Author contributions. LPP and PJG wrote the manuscript with contributions from all co-authors; each co-author was responsible for conducting the numerical simulations of his/her group and making the information available. LPP compiled all the experiments and did the statistical analysis, with the support of PJG.

Competing interests. The authors declare that they have no conflict of interest.

Special issue statement. This article is part of the special issue "Global and regional assessment of intercontinental transport of air pollution: results from HTAP, AQMEII and MICS". It is not associated with a conference.

Acknowledgements. This work was conducted under the support of the AQMEII/HTAP Phase 3 initiative. The authors acknowledge projects REPAIR-CGL2014-59677-R and ACEXCGL2017-87921-R of the Spanish Ministry of Economy and Competitiveness, and the FEDER European program for support to conduct this research. Laura Palacios-Peña acknowledges the FPU scholarship (ref. FPU14/05505) of the Spanish Ministry of Education, Culture and Sport. Gabriele Curci and Paolo Tuccella thank the EuroMediterranean Center for Climate research (CMCC) for providing the computational resources. We also thank the researchers and their staff who have been involved in the MODIS 
datasets (NASA).

Edited by: Nikolaos Mihalopoulos

Reviewed by: three anonymous referees

\section{References}

Ackermann, I. J., Hass, H., Memmesheimer, M., Ebel, A., Binkowski, F. S., and Shankar, U.: Modal aerosol dynamics model for Europe: development and first applications, Atmos. Environ., 32, 2981-2999, https://doi.org/10.1016/S13522310(98)00006-5, 1998.

Ahmadov, R., McKeen, S. A., Robinson, A. L., Bahreini, R., Middlebrook, A. M., de Gouw, J. A., Meagher, J., Hsie, E.-Y., Edgerton, E., Shaw, S., and Trainer, M.: A volatility basis set model for summertime secondary organic aerosols over the eastern United States in 2006, J. Geophys. Res.-Atmos., 117, D06301, https://doi.org/10.1029/2011JD016831, 2012.

Altaratz, O., Bar-Or, R. Z., Wollner, U., and Koren, I.: Relative humidity and its effect on aerosol optical depth in the vicinity of convective clouds, Environ. Res. Lett., 8, 034025, https://doi.org/10.1088/1748-9326/8/3/034025, 2013.

Ångström, A.: On the atmospheric transmission of sun radiation and on dust in the air, Geogr. Ann., 11, 156-166, 1929.

Balzarini, A.: Implementing the WRF-Chem modeling system to investigate the interactions between air quality and meteorology, $\mathrm{PhD}$ thesis, University of Milano-Bicocca, 2013.

Balzarini, A., Pirovano, G., Honzak, L., Ẑabkar, R., Curci, G., Forkel, R., Hirtl, M., San José, R., Tuccella, P., and Grell, G.: WRF-Chem model sensitivity to chemical mechanisms choice in reconstructing aerosol optical properties, Atmos. Environ., 115, 604-619, https://doi.org/10.1016/j.atmosenv.2014.12.033, 2015.

Barnard, J. C., Fast, J. D., Paredes-Miranda, G., Arnott, W. P., and Laskin, A.: Technical Note: Evaluation of the WRF-Chem "Aerosol Chemical to Aerosol Optical Properties" Module using data from the MILAGRO campaign, Atmos. Chem. Phys., 10, 7325-7340, https://doi.org/10.5194/acp-10-7325-2010, 2010.

Baró, R., Lorente-Plazas, R., Montávez, J. P., and JiménezGuerrero, P.: Biomass burning aerosol impact on surface winds during the 2010 Russian heat wave, Geophys. Res. Lett., 44, 2016GL071484, https://doi.org/10.1002/2016GL071484, 2017.

Baró, R., Jiménez-Guerrero, P., Stengel, M., Brunner, D., Curci, G., Forkel, R., Neal, L., Palacios-Peña, L., Savage, N., Schaap, M., Tuccella, P., Denier van der Gon, H., and Galmarini, S.: Evaluating cloud properties in an ensemble of regional online coupled models against satellite observations, Atmos. Chem. Phys., 18, 15183-15199, https://doi.org/10.5194/acp-18-151832018, 2018.

Bilal, M., Nazeer, M., Qiu, Z., Ding, X., and Wei, J.: Global Validation of MODIS C6 and C6. 1 Merged Aerosol Products over Diverse Vegetated Surfaces, Remote Sensing, 10, 475, https://doi.org/10.3390/rs10030475, 2018.

Boucher, O.: Atmospheric Aerosols: Properties and Climate Impacts, Springer, 2015.

Boucher, O., Randall, D., Artaxo, P., Bretherton, C., Feingold, G., Forster, P., Kerminen, V.-M., Kondo, Y., Liao, H., Lohmann, U., Rasch, P., Satheesh, S., Sherwood, S., Stevens, B., and Zhang, X.: Clouds and aerosols, in: Climate change 2013: The physical science basis, Contribution of working group I to the fifth assessment report of the intergovernmental panel on climate change, 571-657, Cambridge University Press, 2013.

Chapman, E. G., Gustafson Jr., W. I., Easter, R. C., Barnard, J. C., Ghan, S. J., Pekour, M. S., and Fast, J. D.: Coupling aerosol-cloud-radiative processes in the WRF-Chem model: Investigating the radiative impact of elevated point sources, Atmos. Chem. Phys., 9, 945-964, https://doi.org/10.5194/acp-9945-2009, 2009.

Chin, M., Ginoux, P., Kinne, S., Torres, O., Holben, B. N., Duncan, B. N., Martin, R. V., Logan, J. A., Higurashi, A., and Nakajima, T.: Tropospheric aerosol optical thickness from the GOCART model and comparisons with satellite and Sun photometer measurements, J. Atmos. Sci., 59, 461-483, 2002.

Colarco, P., da Silva, A., Chin, M., and Diehl, T.: Online simulations of global aerosol distributions in the NASA GEOS-4 model and comparisons to satellite and ground-based aerosol optical depth, J. Geophys. Res.-Atmos., 115, D14207, https://doi.org/10.1029/2009JD012820, 2010.

Collins, W. J., Lamarque, J.-F., Schulz, M., Boucher, O., Eyring, V., Hegglin, M. I., Maycock, A., Myhre, G., Prather, M., Shindell, D., and Smith, S. J.: AerChemMIP: quantifying the effects of chemistry and aerosols in CMIP6, Geosci. Model Dev., 10, 585607, https://doi.org/10.5194/gmd-10-585-2017, 2017.

Curci, G., Alyuz, U., Baró, R., Bianconi, R., Bieser, J., Christensen, J. H., Colette, A., Farrow, A., Francis, X., Jiménez-Guerrero, P., Im, U., Liu, P., Manders, A., Palacios-Peña, L., Prank, M., Pozzoli, L., Sokhi, R., Solazzo, E., Tuccella, P., Unal, A., Vivanco, M. G., Hogrefe, C., and Galmarini, S.: Modelling black carbon absorption of solar radiation: combining external and internal mixing assumptions, Atmos. Chem. Phys., 19, 181-204, https://doi.org/10.5194/acp-19-181-2019, 2019.

de Leeuw, G., Neele, F. P., Hill, M., Smith, M. H., and Vignati, E.: Production of sea spray aerosol in the surf zone, J. Geophys. Res.-Atmos., 105, 29397-29409, https://doi.org/10.1029/2000JD900549, 2000.

Dentener, F., Galmarini, S., Hogrefe, C., Carmichael, G., Law, K., and Denby, B. (Eds.): Global and regional assessment of intercontinental transport of air pollution: results from HTAP, AQMEII and MICS, Atmos. Chem. Phys., https://www. atmos-chem-phys.net/special_issue390.html, 2015.

Donahue, N. M., Robinson, A. L., Stanier, C. O., and Pandis, S. N.: Coupled partitioning, dilution, and chemical aging of semivolatile organics, Environ. Sci. Technol., 40, 2635-2643, https://doi.org/10.1021/es052297c, 2006.

Eck, T. F., Holben, B. N., Reid, J. S., Dubovik, O., Smirnov, A., O'Neill, N. T., Slutsker, I., and Kinne, S.: Wavelength dependence of the optical depth of biomass burning, urban, and desert dust aerosols, J. Geophys. Res.-Atmos., 104, 3133331349, https://doi.org/10.1029/1999JD900923, 1999.

ENVIRON: User's Guide to the Comprehensive Air Quality Model with Extensions Version 5.40, ENVIRON International Corporation, Novato, CA., available at: http://www.camx.com (last access: 20 October 2017), 2014.

Eyring, V., Lamarque, J.-F., Hess, P., Arfeuille, F., Bowman, K., Chipperfield, M. P., Duncan, B., Fiore, A., Gettelman, A., Giorgetta, M. A., Granier, C., Hegglin, M., Kinnison, D., Kunze, M., Langematz, U., Luo, B., Martin, R., Matthes, K., Newman, P. A., Peter, T., Robock, A., Ryerson, T., Saiz-Lopez, A., Salawitch, 
R., Schultz, M., Shepherd, T. G., Shindell, D., Stähelin, J., Tegtmeier, S., Thomason, L., Tilmes, S., Vernier, J.-P., Waugh, D. W., and Young, P. J.: Overview of IGAC/SPARC Chemistry-Climate Model Initiative (CCMI) Community Simulations in Support of Upcoming Ozone and Climate Assessments, SPARC Newsletter, 48-66, 2013.

Eyring, V., Bony, S., Meehl, G. A., Senior, C. A., Stevens, B., Stouffer, R. J., and Taylor, K. E.: Overview of the Coupled Model Intercomparison Project Phase 6 (CMIP6) experimental design and organization, Geosci. Model Dev., 9, 1937-1958, https://doi.org/10.5194/gmd-9-1937-2016, 2016.

Fast, J. D., Gustafson, W. I., Easter, R. C., Zaveri, R. A., Barnard, J. C., Chapman, E. G., Grell, G. A., and Peckham, S. E.: Evolution of ozone, particulates, and aerosol direct radiative forcing in the vicinity of Houston using a fully coupled meteorology-chemistry-aerosol model, J. Geophys. Res.-Atmos., 111, D21305, https://doi.org/10.1029/2005JD006721, 2006.

Forkel, R., Balzarini, A., Baró, R., Bianconi, R., Curci, G., JiménezGuerrero, P., Hirtl, M., Honzak, L., Lorenz, C., Im, U., Pérez, J. L., Pirovano, G., San José, R., Tuccella, P., Werhahn, J., and Żabkar, R.: Analysis of the WRF-Chem contributions to AQMEII phase2 with respect to aerosol radiative feedbacks on meteorology and pollutant distributions, Atmos. Environ., 115, 630-645, https://doi.org/10.1016/j.atmosenv.2014.10.056, 2015.

Forkel, R., Brunner, D., Baklanov, A., Balzarini, A., Hirtl, M., Honzak, L., Jiménez-Guerrero, P., Jorba, O., Pérez, J. L., San José, R., Schröder, W., Tsegas, G., Werhahn, J., Wolke, R., and Žabkar, R.: A Multi-model Case Study on Aerosol Feedbacks in Online Coupled Chemistry-Meteorology Models Within the COST Action ES1004 EuMetChem, in: Air Pollution Modeling and its Application XXIV, 23-28, Springer, 2016.

Fuzzi, S., Baltensperger, U., Carslaw, K., Decesari, S., Denier van der Gon, H., Facchini, M. C., Fowler, D., Koren, I., Langford, B., Lohmann, U., Nemitz, E., Pandis, S., Riipinen, I., Rudich, Y., Schaap, M., Slowik, J. G., Spracklen, D. V., Vignati, E., Wild, M., Williams, M., and Gilardoni, S.: Particulate matter, air quality and climate: lessons learned and future needs, Atmos. Chem. Phys., 15, 8217-8299, https://doi.org/10.5194/acp15-8217-2015, 2015.

Galmarini, S., Rao, S. T., and Steyn, D. G.: Preface to the AQMEII p1 Special issue, Atmos. Environ., 53, 1-3, 2012.

Galmarini, S., Hogrefe, C., Brunner, D., Makar, P., and Baklanov, A.: Preface, Atmos. Environ., 115, 340-344, 2015.

Galmarini, S., Koffi, B., Solazzo, E., Keating, T., Hogrefe, C., Schulz, M., Benedictow, A., Griesfeller, J. J., JanssensMaenhout, G., Carmichael, G., Fu, J., and Dentener, F.: Technical note: Coordination and harmonization of the multi-scale, multi-model activities HTAP2, AQMEII3, and MICS-Asia3: simulations, emission inventories, boundary conditions, and model output formats, Atmos. Chem. Phys., 17, 1543-1555, https://doi.org/10.5194/acp-17-1543-2017, 2017.

Ghan, S., Laulainen, N., Easter, R., Wagener, R., Nemesure, S., Chapman, E., Zhang, Y., and Leung, R.: Evaluation of aerosol direct radiative forcing in MIRAGE, J. Geophys. Res.-Atmos., 106, 5295-5316, https://doi.org/10.1029/2000JD900502, 2001.

Ginoux, P., Chin, M., Tegen, I., Prospero, J. M., Holben, B., Dubovik, O., and Lin, S.-J.: Sources and distributions of dust aerosols simulated with the GOCART model, J. Geophys. Res.-Atmos., 106, 20255-20273, https://doi.org/10.1029/2000JD000053, 2001.

Ginoux, P., Horowitz, L. W., Ramaswamy, V., Geogdzhayev, I. V., Holben, B. N., Stenchikov, G., and Tie, X.: Evaluation of aerosol distribution and optical depth in the Geophysical Fluid Dynamics Laboratory coupled model CM2.1 for present climate, J. Geophys. Res.-Atmos., 111, D22210, https://doi.org/10.1029/2005JD006707, 2006.

Gong, S. L.: A parameterization of sea-salt aerosol source function for sub- and super-micron particles, Global Biogeochem. Cy., 17, 1097, https://doi.org/10.1029/2003GB002079, 2003.

Grell, G. A., Peckham, S. E., Schmitz, R., McKeen, S. A., Frost, G., Skamarock, W. C., and Eder, B.: Fully coupled "online" chemistry within the WRF model, Atmos. Environ., 39, 6957-6975, https://doi.org/10.1016/j.atmosenv.2005.04.027, 2005.

Guenther, A., Karl, T., Harley, P., Wiedinmyer, C., Palmer, P. I., and Geron, C.: Estimates of global terrestrial isoprene emissions using MEGAN (Model of Emissions of Gases and Aerosols from Nature), Atmos. Chem. Phys., 6, 3181-3210, https://doi.org/10.5194/acp-6-3181-2006, 2006.

Hess, M., Koepke, P., and Schult, I.: Optical Properties of Aerosols and Clouds: The Software Package OPAC, B. Am. Meteorol. Soc., 79, 831-844, 1998.

Holben, B. N., Eck, T. F., Slutsker, I., Tanré, D., Buis, J. P., Setzer, A., Vermote, E., Reagan, J. A., Kaufman, Y. J., Nakajima, T., Lavenu, F., Jankowiak, I., and Smirnov, A.: AERONET - A federated instrument network and data archive for aerosol characterization, Remote Sens. Environ., 66, 1-16, 1998.

Ignatov, A., Stowe, L., and Singh, R.: Sensitivity study of the Ångström exponent derived from AVHRR over the oceans, Adv. Space Res., 21, 439-442, 1998.

Im, U., Bianconi, R., Solazzo, E., Kioutsioukis, I., Badia, A., Balzarini, A., Baró, R., Bellasio, R., Brunner, D., Chemel, C., Curci, G., van der Gon, H. D., Flemming, J., Forkel, R., Giordano, L., Jiménez-Guerrero, P., Hirtl, M., Hodzic, A., Honzak, L., Jorba, O., Knote, C., Makar, P. A., Manders-Groot, A., Neal, L., Pérez, J. L., Pirovano, G., Pouliot, G., San José, R., Savage, N., Schroder, W., Sokhi, R. S., Syrakov, D., Torian, A., Tuccella, P., Wang, K., Werhahn, J., Wolke, R., Zabkar, R., Zhang, Y., Zhang, J., Hogrefe, C., and Galmarini, S.: Evaluation of operational online-coupled regional air quality models over Europe and North America in the context of $\{$ AQMEII $\}$ phase 2. Part II: Particulate matter, Atmos. Environ., 115, 421-441, https://doi.org/10.1016/j.atmosenv.2014.08.072, 2015.

Janssens-Maenhout, G., Crippa, M., Guizzardi, D., Dentener, F., Muntean, M., Pouliot, G., Keating, T., Zhang, Q., Kurokawa, J., Wankmüller, R., Denier van der Gon, H., Kuenen, J. J. P., Klimont, Z., Frost, G., Darras, S., Koffi, B., and Li, M.: HTAP_v2.2: a mosaic of regional and global emission grid maps for 2008 and 2010 to study hemispheric transport of air pollution, Atmos. Chem. Phys., 15, 11411-11432, https://doi.org/10.5194/acp-15-11411-2015, 2015.

Jeuken, A., Veefkind, J. P., Dentener, F., Metzger, S., and Gonzalez, C. R.: Simulation of the aerosol optical depth over Europe for August 1997 and a comparison with observations, J. Geophys. Res.-Atmos., 106, 28295-28311, https://doi.org/10.1029/2001JD900063, 2001.

Kim, S.-W., Heckel, A., Frost, G. J., Richter, A., Gleason, J., Burrows, J. P., McKeen, S., Hsie, E.-Y., Granier, C., and Trainer, M.: 
$\mathrm{NO}_{2}$ columns in the western United States observed from space and simulated by a regional chemistry model and their implications for $\mathrm{NO}_{x}$ emissions, J. Geophys. Res.-Atmos., 114, D11301, https://doi.org/10.1029/2008JD011343, 2009.

Kinne, S., Lohmann, U., Feichter, J., Schulz, M., Timmreck, C., Ghan, S., Easter, R., Chin, M., Ginoux, P., Takemura, T., Tegen, I., Koch, D., Herzog, M., Penner, J., Pitari, G., Holben, B., Eck, T., Smirnov, A., Dubovik, O., Slutsker, I., Tanre, D., Torres, O., Mishchenko, M., Geogdzhayev, I., Chu, D. A., and Kaufman, Y.: Monthly averages of aerosol properties: A global comparison among models, satellite data, and AERONET ground data, J. Geophys. Res.-Atmos., 108, 4634, https://doi.org/10.1029/2001JD001253, 2003.

Kinne, S., Schulz, M., Textor, C., Guibert, S., Balkanski, Y., Bauer, S. E., Berntsen, T., Berglen, T. F., Boucher, O., Chin, M., Collins, W., Dentener, F., Diehl, T., Easter, R., Feichter, J., Fillmore, D., Ghan, S., Ginoux, P., Gong, S., Grini, A., Hendricks, J., Herzog, M., Horowitz, L., Isaksen, I., Iversen, T., Kirkevåg, A., Kloster, S., Koch, D., Kristjansson, J. E., Krol, M., Lauer, A., Lamarque, J. F., Lesins, G., Liu, X., Lohmann, U., Montanaro, V., Myhre, G., Penner, J., Pitari, G., Reddy, S., Seland, O., Stier, P., Takemura, T., and Tie, X.: An AeroCom initial assessment - optical properties in aerosol component modules of global models, Atmos. Chem. Phys., 6, 1815-1834, https://doi.org/10.5194/acp-61815-2006, 2006.

Kong, X., Forkel, R., Sokhi, R. S., Suppan, P., Baklanov, A., Gauss, M., Brunner, D., Baró, R., Balzarini, A., Chemel, C., Curci, G., Jiménez-Guerrero, P., Hirtl, M., Honzak, L., Im, U., Pérez, J. L., Pirovano, G., San José, R., Schlünzen, K. H., Tsegas, G., Tuccella, P., Werhahn, J., Żabkar, R., and Galmarini, S.: Analysis of meteorology-chemistry interactions during air pollution episodes using online coupled models within AQMEII phase-2, Atmos. Environ., 115, 527-540, https://doi.org/10.1016/j.atmosenv.2014.09.020, 2015.

Kulmala, M., Asmi, A., Lappalainen, H. K., Baltensperger, U., Brenguier, J.-L., Facchini, M. C., Hansson, H.-C., Hov, Ø., O'Dowd, C. D., Pöschl, U., Wiedensohler, A., Boers, R., Boucher, O., de Leeuw, G., Denier van der Gon, H. A. C., Feichter, J., Krejci, R., Laj, P., Lihavainen, H., Lohmann, U., McFiggans, G., Mentel, T., Pilinis, C., Riipinen, I., Schulz, M., Stohl, A., Swietlicki, E., Vignati, E., Alves, C., Amann, M., Ammann, M., Arabas, S., Artaxo, P., Baars, H., Beddows, D. C. S., Bergström, R., Beukes, J. P., Bilde, M., Burkhart, J. F., Canonaco, F., Clegg, S. L., Coe, H., Crumeyrolle, S., D’Anna, B., Decesari, S., Gilardoni, S., Fischer, M., Fjaeraa, A. M., Fountoukis, C., George, C., Gomes, L., Halloran, P., Hamburger, T., Harrison, R. M., Herrmann, H., Hoffmann, T., Hoose, C., Hu, M., Hyvärinen, A., Hõrrak, U., Iinuma, Y., Iversen, T., Josipovic, M., Kanakidou, M., Kiendler-Scharr, A., Kirkevåg, A., Kiss, G., Klimont, Z., Kolmonen, P., Komppula, M., Kristjánsson, J.-E., Laakso, L., Laaksonen, A., Labonnote, L., Lanz, V. A., Lehtinen, K. E. J., Rizzo, L. V., Makkonen, R., Manninen, H. E., McMeeking, G., Merikanto, J., Minikin, A., Mirme, S., Morgan, W. T., Nemitz, E., O’Donnell, D., Panwar, T. S., Pawlowska, H., Petzold, A., Pienaar, J. J., Pio, C., Plass-Duelmer, C., Prévôt, A. S. H., Pryor, S., Reddington, C. L., Roberts, G., Rosenfeld, D., Schwarz, J., Seland, Ø., Sellegri, K., Shen, X. J., Shiraiwa, M., Siebert, H., Sierau, B., Simpson, D., Sun, J. Y., Topping, D., Tunved, P., Vaattovaara, P., Vakkari, V., Veefkind,
J. P., Visschedijk, A., Vuollekoski, H., Vuolo, R., Wehner, B., Wildt, J., Woodward, S., Worsnop, D. R., van Zadelhoff, G.J., Zardini, A. A., Zhang, K., van Zyl, P. G., Kerminen, V.M., S Carslaw, K., and Pandis, S. N.: General overview: European Integrated project on Aerosol Cloud Climate and Air Quality interactions (EUCAARI); integrating aerosol research from nano to global scales, Atmos. Chem. Phys., 11, 13061-13143, https://doi.org/10.5194/acp-11-13061-2011, 2011.

Landi, T. C.: AODEM, ISBN 10: 3659318027/ISBN 13: 9783659318023, LAP Lambert Academic Publishing, 2013.

Levy, R. C., Mattoo, S., Munchak, L. A., Remer, L. A., Sayer, A. M., Patadia, F., and Hsu, N. C.: The Collection 6 MODIS aerosol products over land and ocean, Atmos. Meas. Tech., 6, 29893034, https://doi.org/10.5194/amt-6-2989-2013, 2013.

Liu, X., Easter, R. C., Ghan, S. J., Zaveri, R., Rasch, P., Shi, X., Lamarque, J.-F., Gettelman, A., Morrison, H., Vitt, F., Conley, A., Park, S., Neale, R., Hannay, C., Ekman, A. M. L., Hess, P., Mahowald, N., Collins, W., Iacono, M. J., Bretherton, C. S., Flanner, M. G., and Mitchell, D.: Toward a minimal representation of aerosols in climate models: description and evaluation in the Community Atmosphere Model CAM5, Geosci. Model Dev., 5, 709-739, https://doi.org/10.5194/gmd-5-709-2012, 2012.

Makar, P., Gong, W., Hogrefe, C., Zhang, Y., Curci, G., Źabkar, R., Milbrandt, J., Im, U., Balzarini, A., Baró, R., Bianconi, R., Cheung, P., Forkel, R., Gravel, S., Hirtl, M., Honzak, L., Hou, A., Jiménez-Guerrero, P., Langer, M., Moran, M., Pabla, B., Pérez, J., Pirovano, G., San José, R., Tuccella, P., Werhahn, J., Zhang, J., and Galmarini, S.: Feedbacks between air pollution and weather, part 2: Effects on chemistry, Atmos. Environ., 115, 499-526, https://doi.org/10.1016/j.atmosenv.2014.10.021, 2015.

Mhawish, A., Banerjee, T., Broday, D. M., Misra, A., and Tripathi, S. N.: Evaluation of MODIS Collection 6 aerosol retrieval algorithms over Indo-Gangetic Plain: Implications of aerosols types and mass loading, Remote Sens. Environ., 201, 297-313, 2017.

Moorthy, K. K., Satheesh, S. K., Babu, S. S., and Dutt, C. B. S.: Integrated Campaign for Aerosols, gases and Radiation Budget (ICARB): An overview, J. Earth Syst. Sci., 117, 243-262, https://doi.org/10.1007/s12040-008-0029-7, 2008.

NASA Official: MODIS atmosphere, available at: https: //modis-atmos.gsfc.nasa.gov/MOD04_L2/acquiring.html, last access: 18 October 2017.

Ogren, J.: WMO/GAW Standard Operating Procedures for In-Situ Measurements of Aerosol Mass Concentration, Light Scattering and Light Absorption, WMO/GAW, Tech. rep., World Meteorological Organization Report, 2011.

Palacios-Peña, L., Baró, R., Guerrero-Rascado, J. L., AladosArboledas, L., Brunner, D., and Jiménez-Guerrero, P.: Evaluating the representation of aerosol optical properties using an online coupled model over the Iberian Peninsula, Atmos. Chem. Phys., 17, 277-296, https://doi.org/10.5194/acp-17-277-2017, 2017.

Palacios-Peña, L., Baró, R., Baklanov, A., Balzarini, A., Brunner, D., Forkel, R., Hirtl, M., Honzak, L., López-Romero, J. M., Montávez, J. P., Pérez, J. L., Pirovano, G., San José, R., Schröder, W., Werhahn, J., Wolke, R., Žabkar, R., and Jiménez-Guerrero, P.: An assessment of aerosol optical properties from remotesensing observations and regional chemistry-climate coupled models over Europe, Atmos. Chem. Phys., 18, 5021-5043, https://doi.org/10.5194/acp-18-5021-2018, 2018. 
Paredes-Miranda, G., Arnott, W. P., Jimenez, J. L., Aiken, A. C., Gaffney, J. S., and Marley, N. A.: Primary and secondary contributions to aerosol light scattering and absorption in Mexico City during the MILAGRO 2006 campaign, Atmos. Chem. Phys., 9, 3721-3730, https://doi.org/10.5194/acp-9-3721-2009, 2009.

Permadi, D. A., Kim Oanh, N. T., and Vautard, R.: Integrated emission inventory and modeling to assess distribution of particulate matter mass and black carbon composition in Southeast Asia, Atmos. Chem. Phys., 18, 2725-2747, https://doi.org/10.5194/acp18-2725-2018, 2018.

Pouliot, G., Pierce, T., van der Gon, H. D., Schaap, M., Moran, M., and Nopmongcol, U.: Comparing emission inventories and model-ready emission datasets between Europe and North America for the AQMEII project, Atmos. Environ., 53, 4-14, 2012.

Pouliot, G., van der Gon, H. A. D., Kuenen, J., Zhang, J., Moran, M. D., and Makar, P. A.: Analysis of the emission inventories and model-ready emission datasets of Europe and North America for phase 2 of the AQMEII project, Atmos. Environ., 115, 345-360, 2015.

Poupkou, A., Giannaros, T., Markakis, K., Kioutsioukis, I., Curci, G., Melas, D., and Zerefos, C.: A model for European biogenic volatile organic compound emissions: software development and first validation, Environ. Modell. Softw., 25, 1845-1856, 2010.

Randall, D. A., Wood, R. A., Bony, S., Colman, R., Fichefet, T., Fyfe, J., Kattsov, V., Pitman, A., Shukla, J., Srinivasan, J., Stouffer, R. J., Sumi, A., and Taylor, K. E.: Climate models and their evaluation, in: Climate change 2007: The physical science basis. Contribution of Working Group I to the Fourth Assessment Report of the IPCC (FAR), 589-662, Cambridge University Press, 2007

Rao, S. T., Galmarini, S., and Puckett, K.: Air Quality Model Evaluation International Initiative (AQMEII): Advancing the State of the Science in Regional Photochemical Modeling and Its Applications, B. Am. Meteorol. Soc., 92, 23-30, https://doi.org/10.1175/2010BAMS3069.1, 2011.

Reddy, M. S., Boucher, O., Bellouin, N., Schulz, M., Balkanski, Y., Dufresne, J.-L., and Pham, M.: Estimates of global multicomponent aerosol optical depth and direct radiative perturbation in the Laboratoire de Météorologie Dynamique general circulation model, J. Geophys. Res.-Atmos., 110, D10S16, https://doi.org/10.1029/2004JD004757, 2005.

Remer, L. A., Kaufman, Y., Tanré, D., Mattoo, S., Chu, D., Martins, J. V., Li, R.-R., Ichoku, C., Levy, R., Kleidman, R., Eck, T. F., E, V., and Holben, B. N.: The MODIS aerosol algorithm, products, and validation, J. Atmos. Sci., 62, 947-973, 2005.

Romakkaniemi, S., Arola, A., Kokkola, H., Birmili, W., Tuch, T., Kerminen, V.-M., Räisänen, P., Smith, J. N., Korhonen, H., and Laaksonen, A.: Effect of aerosol size distribution changes on $\mathrm{AOD}, \mathrm{CCN}$ and cloud droplet concentration: Case studies from Erfurt and Melpitz, Germany, J. Geophys. Res.-Atmos., 117, D07202, https://doi.org/10.1029/2011JD017091, 2012.

Sayer, A., Munchak, L., Hsu, N., Levy, R., Bettenhausen, C., and Jeong, M.-J.: MODIS Collection 6 aerosol products: Comparison between Aqua's e-Deep Blue, Dark Target, and "merged" data sets, and usage recommendations, J. Geophys. Res.-Atmos., 119, 13965-13989 https://doi.org/10.1002/2014JD022453, 2014.

Schell, B., Ackermann, I. J., Hass, H., Binkowski, F. S., and Ebel, A.: Modeling the formation of secondary organic aerosol within a comprehensive air quality model system, J. Geophys. Res.-Atmos., 106, 28275-28293, https://doi.org/10.1029/2001JD000384, 2001.

Schulz, M., Chin, M., and Kinne, S.: The aerosol model comparison project, AeroCom, phase II: Clearing up diversity, IGAC Newsletter, 2009.

Shaw, W. J., Allwine, K. J., Fritz, B. G., Rutz, F. C., Rishel, J. P., and Chapman, E. G.: An evaluation of the wind erosion module in DUSTRAN, Atmos. Environ., 42, 1907-1921, https://doi.org/10.1016/j.atmosenv.2007.11.022, 2008.

Smirnov, A., Holben, B. N., Slutsker, I., Giles, D. M., McClain, C. R., Eck, T. F., Sakerin, S. M., Macke, A., Croot, P., Zibordi, G., Quinn, P. K., Sciare, J., Kinne, S., Harvey, M., Smyth, T. J., Piketh, S., Zielinski, T., Proshutinsky, A., Goes, J. I., Nelson, N. B., Larouche, P., Radionov, V. F., Goloub, P., Krishna Moorthy, K., Matarrese, R., Robertson, E. J., and Jourdin, F.: Maritime Aerosol Network as a component of Aerosol Robotic Network, J. Geophys. Res.-Atmos., 114, D011257 https://doi.org/10.1029/2008JD011257, 2009.

Soares, J., Sofiev, M., and Hakkarainen, J.: Uncertainties of wildland fires emission in AQMEII phase 2 case study, Atmos. Environ., 115, 361-370, 2015.

Sofiev, M.: A model for the evaluation of long-term airborne pollution transport at regional and continental scales, Atmos. Environ., 34, 2481-2493, 2000.

Sofiev, M., Soares, J., Prank, M., de Leeuw, G., and Kukkonen, J.: A regional-to-global model of emission and transport of sea salt particles in the atmosphere, J. Geophys. Res.-Atmos., 116, D21302, https://doi.org/10.1029/2010JD014713, 2011.

Sofiev, M., Vira, J., Kouznetsov, R., Prank, M., Soares, J., and Genikhovich, E.: Construction of the SILAM Eulerian atmospheric dispersion model based on the advection algorithm of Michael Galperin, Geosci. Model Dev., 8, 3497-3522, https://doi.org/10.5194/gmd-8-3497-2015, 2015.

Solazzo, E., Bianconi, R., Pirovano, G., Matthias, V., Vautard, R., Moran, M. D., Appel, K. W., Bessagnet, B., Brandt, J., Christensen, J. H., Chemel, C., Coll, I., Ferreira, J., Forkel, R., Francis, X. V., Grell, G., Grossi, P., Hansen, A. B., Miranda, A. I., Nopmongcol, U., Prank, M., Sartelet, K. N., Schaap, M., Silver, J. D., Sokhi, R. S., Vira, J., Werhahn, J., Wolke, R., Yarwood, G., Zhang, J., Rao, S. T., and Galmarini, S.: Operational model evaluation for particulate matter in Europe and North America in the context of AQMEII, Atmos. Environ., 53, 75-92, https://doi.org/10.1016/j.atmosenv.2012.02.045, 2012.

Solazzo, E., Galmarini, S., Bianconi, R., and Rao, S. T.: Model evaluation for surface concentration of particulate matter in Europe and North America in the context of AQMEII, in: Air Pollution Modeling and its Application XXII, 375-379, Springer, 2014.

Solazzo, E., Bianconi, R., Hogrefe, C., Curci, G., Tuccella, P., Alyuz, U., Balzarini, A., Baró, R., Bellasio, R., Bieser, J., Brandt, J., Christensen, J. H., Colette, A., Francis, X., Fraser, A., Vivanco, M. G., Jiménez-Guerrero, P., Im, U., Manders, A., Nopmongcol, U., Kitwiroon, N., Pirovano, G., Pozzoli, L., Prank, M., Sokhi, R. S., Unal, A., Yarwood, G., and Galmarini, S.: Evaluation and error apportionment of an ensemble of atmospheric chemistry transport modeling systems: multivariable temporal and spatial breakdown, Atmos. Chem. Phys., 17, 3001-3054, https://doi.org/10.5194/acp-17-3001-2017, 2017.

Solmon, F., Giorgi, F., and Liousse, C.: Aerosol modelling for regional climate studies: application to anthropogenic particles and 
evaluation over a European/African domain, Tellus B, 58, 51-72, 2006.

Stockwell, W. R., Middleton, P., Chang, J. S., and Tang, X.: The second generation regional acid deposition model chemical mechanism for regional air quality modeling, J. Geophys. Res.-Atmos., 95, 16343-16367, https://doi.org/10.1029/JD095iD10p16343, 1990.

Toll, V., Reis, K., Ots, R., Kaasik, M., Männik, A., Prank, M., and Sofiev, M.: SILAM and MACC reanalysis aerosol data used for simulating the aerosol direct radiative effect with the NWP model HARMONIE for summer 2010 wildfire case in Russia, Atmos. Environ., 121, 75-85, https://doi.org/10.1016/j.atmosenv.2015.06.007, 2015a.

Toll, V., Reis, K., Ots, R., Kaasik, M., Männik, A., Prank, M., and Sofiev, M.: SILAM and MACC reanalysis aerosol data used for simulating the aerosol direct radiative effect with the NWP model HARMONIE for summer 2010 wildfire case in Russia, Atmos. Environ., 121, 75-85, 2015 b.

Tørseth, K., Aas, W., Breivik, K., Fjæraa, A. M., Fiebig, M., Hjellbrekke, A. G., Lund Myhre, C., Solberg, S., and Yttri, K. E.: Introduction to the European Monitoring and Evaluation Programme (EMEP) and observed atmospheric composition change during 1972-2009, Atmos. Chem. Phys., 12, 5447-5481, https://doi.org/10.5194/acp-12-5447-2012, 2012.

Tuccella, P., Curci, G., Visconti, G., Bessagnet, B., Menut, L., and Park, R. J.: Modeling of gas and aerosol with WRF/Chem over Europe: Evaluation and sensitivity study, J. Geophys. Res.Atmos., 117, D03303, https://doi.org/10.1029/2011JD016302, 2012.

Tuccella, P., Curci, G., Grell, G. A., Visconti, G., Crumeyrolle, S., Schwarzenboeck, A., and Mensah, A. A.: A new chemistry option in WRF-Chem v. 3.4 for the simulation of direct and indirect aerosol effects using VBS: evaluation against IMPACT-EUCAARI data, Geosci. Model Dev., 8, 2749-2776, https://doi.org/10.5194/gmd-8-2749-2015, 2015.

Wang, K., Yahya, K., Zhang, Y., Hogrefe, C., Pouliot, G., Knote, C., Hodzic, A., San José, R., Pérez, J. L., Jiménez-Guerrero, P., Baró, R., Makar, P., and Bennartz, R.: A multi-model assessment for the 2006 and 2010 simulations under the Air Quality Model Evaluation International Initiative (AQMEII) Phase 2 over North America: Part II. Evaluation of column variable predictions using satellite data, Atmos. Environ., 115, 587-603, https://doi.org/10.1016/j.atmosenv.2014.07.044, 2015.
Warneke, C., Froyd, K. D., Brioude, J., Bahreini, R., Brock, C. A., Cozic, J., de Gouw, J. A., Fahey, D. W., Ferrare, R., Holloway, J. S., Middlebrook, A. M., Miller, L., Montzka, S., Schwarz, J. P., Sodemann, H., Spackman, J. R., and Stohl, A.: An important contribution to springtime Arctic aerosol from biomass burning in Russia, Geophys. Res. Lett., 37, L01801, https://doi.org/10.1029/2009GL041816, 2010.

Weil, J., Sykes, R., and Venkatram, A.: Evaluating air-quality models: review and outlook, J. Appl. Meteorol., 31, 1121-1145, 1992.

Willmott, C. J. and Matsuura, K.: Advantages of the mean absolute error (MAE) over the root mean square error (RMSE) in assessing average model performance, Clim. Res., 30, 79-82, https://doi.org/10.3354/cr030079, 2005.

Willmott, C. J., Ackleson, S. G., Davis, R. E., Feddema, J. J., Klink, K. M., Legates, D. R., O'Donnell, J., and Rowe, C. M.: Statistics for the evaluation and comparison of models, J. Geophys. Res.-Oceans, 90, 8995-9005, https://doi.org/10.1029/JC090iC05p08995, 1985.

Winker, D. M., Pelon, J. R., and McCormick, M. P.: The CALIPSO mission: Spaceborne lidar for observation of aerosols and clouds, in: Third International Asia-Pacific Environmental Remote Sensing Remote Sensing of the Atmosphere, Ocean, Environment, and Space, 1-11, International Society for Optics and Photonics, 2003.

Wooster, M. J., Roberts, G., Perry, G., and Kaufman, Y.: Retrieval of biomass combustion rates and totals from fire radiative power observations: FRP derivation and calibration relationships between biomass consumption and fire radiative energy release, J. Geophys. Res.-Atmos., 110, D24311, https://doi.org/10.1029/2005JD006318, 2005.

Yoon, S.-C. and Kim, J.: Influences of relative humidity on aerosol optical properties and aerosol radiative forcing during ACE-Asia, Atmos. Environ., 40, 4328-4338, https://doi.org/10.1016/j.atmosenv.2006.03.036, 2006.

Zhang, K., O’Donnell, D., Kazil, J., Stier, P., Kinne, S., Lohmann, U., Ferrachat, S., Croft, B., Quaas, J., Wan, H., Rast, S., and Feichter, J.: The global aerosol-climate model ECHAM-HAM, version 2: sensitivity to improvements in process representations, Atmos. Chem. Phys., 12, 8911-8949, https://doi.org/10.5194/acp-12-8911-2012, 2012. 